\title{
EN TORNO AL ORIGEN DE LOS SEÑORÍOS DEL REINO DE JAÉN. LA GÉNESIS DEL LINAJE DE LOS QuESADA, SEÑORES de GarcíEZ y SANTO TOMÉ (JAÉN). SigLos XIII-XIV ${ }^{1}$
}

\author{
María Antonia Carmona Ruiz ${ }^{2}$ \\ Universidad de Sevilla
}

\begin{abstract}
Resumen
Tras la conquista de Andalucía se asentaron numerosos nobles pertenecientes a los estratos medios o inferiores que con el tiempo consolidaron su posición en la región logrando formar algunos señoríos más o menos importantes. Es el caso de los Quesada, prototipo de la nobleza que va a conseguir un notable protagonismo en la vida política, económica y social andaluza. A partir de un personaje de gran prestigio militar como fue Pedro Díaz de Toledo, sería su hijo Día Sánchez de Quesada el verdadero creador del linaje.
\end{abstract}

\section{Palabras clave}

Nobleza andaluza; reino de Jaén; Baeza; Linaje.

\begin{abstract}
After the conquest of Andalusia, many noblemen belonging to the middle or lower strata settled in the region, eventually consolidating their position by creating some more or less important domains. This was the case of the Quesada lineage, a prototype of the kind of nobility that was going to achieve a significant role in Andalusian political, economic and social life. Starting out from Pedro Díaz of Todelo, a character of great military prestige, was his son Día Sánchez of Quesada who became the real creator of the lineage.
\end{abstract}

\section{Keywords}

Andalusian nobility; Kingdom of Jaen; Baeza; Lineage.

\section{Résumé}

Après la conquête de l'Andalousie, s'y fixèrent de nombreux nobles appartenant aux couches moyenne ou inférieure de leur groupe social. Peu à peu, ils sont parvenus à consolider leur position dans la région, où ils ont pu se constituer des seigneuries plus ou moins importantes. Tel est le cas

1 Este trabajo forma parte de los proyectos de investigación financiados por el Ministerio de Economía y Competitividad y que llevan por título: "Iglesia y Escritura en el Reino de Castilla: siglos XIII-XVII" (HAR2013-41378-P) y "Poder, fiscalidad y sociedades fronterizas en la Corona de Castilla al sur del Tajo (siglos XIV-XVI)”. (referencia HAR2014-52469-C3-1-P).

2 Correo electrónico: mantonia@us.es. 
des Quesada, prototype de la noblesse qui finira par jouer un rôle important dans la vie politique, économique et sociale andalouse. À la suite de Pedro Diaz de Toledo, dont le prestige militaire fut grand, c'est son fils, Dia Sanchez de Quesada, qui fut le véritable créateur de la lignée.

\section{Mots-clés}

Noblesse Andalouse; royaume de Jaén; Baeza; lignée.

\section{Introducción}

Una de las características de la nobleza que se asentó en Andalucía tras la conquista fue su pertenencia a sus estratos medios o inferiores, o ser segundones de los principales linajes. Con el tiempo, muchos de ellos fueron consolidando su posición en la región logrando formar unos señoríos, más o menos importantes, a consecuencia, por un lado, de la situación fronteriza con el reino de Granada y por otro, de las luchas políticas que sufrió la Corona de Castilla en los siglos bajomedievales, consiguiendo un notable protagonismo político tanto a escala local como regional, gracias al desempeño de cargos concejiles, oficios militares... ${ }^{3}$. Además, sus relaciones con la monarquía posibilitaron que algunos alcanzaran altas cotas de poder a nivel nacional. El linaje de los Quesada es un claro ejemplo de esta realidad. Procedentes de una de las tantas familias de la pequeña nobleza que llegaron a Andalucía al amparo de la guerra contra Granada, consiguió consolidar su posición en el reino de Jaén, e incluso incrementarla, convirtiéndose en el arquetipo del noble que va a progresar en territorio andaluz.

El presente artículo se centra en la figura de Pedro Díaz de Toledo y de su hijo Día Sánchez de Quesada. El primero establecería las bases fundamentales para el progreso de un linaje que a partir de sus éxitos militares en la frontera con Granada conseguirá ir añadiendo cargos políticos y administrativos, tanto a nivel local como regional. Sería sin embargo su hijo Día Sánchez quien logró consolidar la posición de esta familia, convirtiéndola en una de las más influyentes de la zona, consiguiendo además una importante proyección política en la corte de Pedro I. Fue este último realmente el creador del linaje, utilizando para ello a un personaje -en este caso su padre- considerado glorioso por su actividad militar.

El linaje de los Quesada ha sido objeto de diversos estudios, buena parte de ellos basados principalmente en las noticias que aportan las genealogías clásicas y que en muchos casos han transmitido reiterativamente importantes errores ${ }^{4}$. Sólo María del Mar García Guzmán

\footnotetext{
3 Entre los trabajos dedicados a la evolución del régimen señorial en Andalucía destacamos el ya clásico de Antonio Collantes de Terán, "Los señoríos andaluces. Análisis de su evolución territorial en la Edad Media". Historia. Instituciones. Documentos (en adelante HID), 6 (1979), pp. 89-112, o Emilio CABrerA MuÑoz, "Nobleza y señoríos en Andalucía en la Baja Edad Media" en La nobleza peninsular en la Edad Media, León, Fundación Sánchez Albornoz, 1999, pp. 89-119.

4 Las principales Historias genealógicas que hacen referencia a este linaje son Gonzalo ArGOTE DE MolinA, Nobleza de Andalucía (Jaén, 1991, facs. de la ed. de 1866). Alonso López De HARo, Nobiliario genealógico de los reyes y títulos de España (Madrid, 1622). José Martínez MAzAs, Retrato al natural de la ciudad y término de Jaén... (Jaén. 1794, reimp. Barcelona, 1978). Bartolomé XIMÉnez Patón, Historia de la antigua y continuada nobleza de la ciudad de Iaén... (Jaén, 1983, facs. de la ed. de 1628) dos genealogías anónimas
} 
ha podido contrastar esta información con el análisis de alguna documentación realizando varios trabajos sobre esta familia, aunque centrándose exclusivamente en el estudio de una de sus propiedades: el señorío de Santo Tomé y especialmente en la figura de Pedro Díaz de Toledo ${ }^{5}$. A través del análisis de nuevas fuentes históricas procedentes en su mayoría de distintos archivos nobiliarios, he podido completar y matizar la información con que contábamos para el origen de uno de los pocos linajes que implantados en el reino de Jaén en el siglo XIII logró mantener una continuidad los siglos siguientes.

\section{Pedro Díaz de Toledo}

Según indican los diferentes genealogistas que lo han estudiado, el fundador del linaje fue Pedro Díaz de Toledo, hermano del arzobispo de Toledo Gonzalo Díaz Palomeque y, por lo tanto, sobrino del arzobispo Gonzalo García Gudiel ${ }^{6}$. Pertenecía, pues, a la oligarquía mozárabe toledana, con gran tradición en la carrera eclesiástica y en el servicio a la Corona ${ }^{7}$. Sus aptitudes militares y de mando explican que, durante el gobierno de su tío el arzobispo Gonzalo García Gudiel (1280-1299), se trasladara a las tierras recién conquistadas en Andalucía pertenecientes a la mitra toledana a fin de consolidar su ocupación. A partir de ahí centró toda su actividad en el territorio jiennense, donde además a la función militar añadió la administrativa, integrándose además en la vida política local, consiguiendo acumular el suficiente patrimonio para consolidar la posición de su familia.

\subsection{La actividad militar de Pedro Díaz de Toledo}

Podemos constatar la presencia de Pedro Díaz de Toledo en Andalucía durante el gobierno de su tío Gonzalo García Gudiel a través de un milagro recogido por el monje de Silos, Pedro Marín, que se produjo en 1287, en el que se le denomina "adelantado

conservadas en la Real Academia de la Historia (en adelante RAH), Colección Salazar y Castro, una titulada Genealogya de los cavalleros del apellido ylustre de Quesada, cuio gran pariente es don Hernando de Quesada Mendosa Toledo, conde de Santo Thomé, señor de la Abujada RAH, Colección Salazar 09-00312 (D-37) fols. 1r-90r y otra denominada Asçendençia de los señores de la cassa de Garçiez desde Pedro Díaz de Toledo, primero señor de Garçiez y Santo Thomé que fue hermano de don Gonzalo Palomeque, arzobispo de Toledo. RAH, Colección Salazar, 09-00201 (B-92) f.181r-192v. José Manuel Troyano Viedma realizó varios trabajos en los que se repiten los numerosos errores que estos autores han transmitido en sus obras, sin contrastar los datos con la documentación escrita conservada. $C f r$. José Manuel Troyano Viedma, J. M. La villa de Garciez: historia, arte y tradición. Ayuntamiento de Garcíez, 2007.

$5 \quad M^{a}$ del Mar García Guzmán, "Los orígenes del señorío de Santo Tomé (Jaén) y "Santo Tomé y Pedro Díaz de Toledo. El origen de un linaje jiennense: Los Díaz de Quesada" en El señorío de Cazorla en la Baja Edad Media. Cádiz, 2006, pp. 167-209.

6 Fue arzobispo de Toledo entre 1280 y 1299, habiendo sido anteriormente canónigo de Burgos, arcediano de Toledo, obispo de Cuenca, de Burgos y posteriormente cardenal. Sobre su gobierno vid. Francisco Javier HeRnÁndez y Peter Linehan, The Mozarabic Cardinal. The Life and Times of Gonzalo Pérez Gudiel, Firenze, 2004. 7 Para un mayor conocimiento de la familia vid. Francisco Javier Hernández y Peter Linehan, The Mozarabic Cardinal..., pp. 14 y ss. 
de Quesada"8. Este dato es sumamente interesante principalmente porque es la única ocasión en la que tenemos referencia a este cargo. Posiblemente era el nombre que se le daba al delegado del arzobispo en tierras del sur, y aunque no sabemos exactamente qué funciones comportaban este oficio, debemos suponer que, si eran similares a la del adelantado de la Frontera, o al adelantado de Cazorla, sus competencias debían estar relacionadas con el gobierno, administración y defensa del señorío que los prelados toledanos habían conquistado en el sur peninsular.

Asimismo, la función de "adelantado de Quesada" hacía referencia a otra realidad: que la villa de Quesada era el centro administrativo del territorio desde su conquista, producida en 1231, y que debió ser así hasta 1295, fecha en que cayó en manos de los musulmanes 9 . Esta última circunstancia debió obligar a una restructuración del territorio, convirtiéndose a partir de entonces Cazorla en el centro administrativo del señorío, pasando a denominarse el encargado del gobierno de estas tierras adelantado de Cazorla, aunque hay bastantes problemas a la hora de dilucidar desde cuando existía este cargo.

Numerosas genealogías indican que Gonzalo Díaz Palomeque, nombrado arzobispo de Toledo en 1299, dio el título de adelantado de Cazorla a su hermano Pedro Díaz de Toledo, e incluso algunos le señalan como el primero que tuvo ese $\operatorname{cargo}^{10}$. Sin embargo, en la documentación coetánea que ha llegado a nuestros días no se menciona nunca a Pedro Díaz con ese título. De hecho, se conservan tan sólo tres documentos relacionados con Pedro Díaz, que fueron emitidos en las fechas en las que Gonzalo Díaz Palomeque era arzobispo de Toledo ${ }^{11}$, y en todos ellos se le identifica como hermano del prelado toledano, sin indicarse que tuviera ningún tipo de cargo ${ }^{12}$. Ello ha llevado

\footnotetext{
8 Se relata cómo un tal Sancho de Úbeda, cautivo en Guadix, consiguió escapar de su señor a caballo, y que después de llegar a Torres de Alicún, Pedro Díaz, "adelantado de Quesada, mandól sacar los fierros, e porque eran paçes, tomól el cauallo e enbiól a su sennor". Manuel GonZÁLEZ JimÉnEZ y Ángel Luis Molina Molina, Los milagros romanzados de Santo Domingo de Silos de Pero Marín, Murcia, 2008, p. 165 , milagro $\mathrm{n}^{\circ} 88$.

9 Rachel ARIÉ, L'Espagne musulmane au temps des Nasrides (1232-1492), París, 1973, pp. 80-81; Juan de Mata Carriazo, Colección Diplomática de Quesada, Jaén, 1975, LXIX; Miguel Ángel Ladero Quesada, Granada. Historia de un país islámico (1232-1571), Madrid, 1979, p. 80; Juan Francisco Rivera Recio, El Adelantamiento de Cazorla. Historia General. Toledo, 1948, p. 27.

10 Gonzalo Argote de Molina, Nobleza..., p. 353, cuenta que "era arzobispo de Toledo D. Gonzalo Palomeque, por el cual era adelantado de Cazorla Pedro Diaz de Toledo". En Asçendençia de los señores de la cassa de Garçiez... RAH, Colección Salazar, 09-00201 (B-92) se dice "Poseyendo pues la silla arzouispal de Toledo D. Gonzalo Palomeque, que según el arçobispo D. Juan de Ábila escribe que fue el primero adelantado de Caçorla". En la Genealogya de los cavalleros del apellido ylustre de Quesada... RAH, Colección Salazar 09-00312 (D-37) f.1r-90r se indica que "le dio su hermano D. Gonzalo Palomeque, arzobispo de Toledo, el adelantamiento de Cazorla y fue su primer adelantado". Bartolomé XIMÉNEz PATÓN, Historia de la antigua y continuada nobleza de la ciudad de Iaén... fol. 171v. también señala que fue el primer adelantado de Cazorla.

11 Gonzalo Diaz Palomeque fue arzobispo de Toledo entre 1299 y 1310.

12 El primero de ellos es de 1300, emitido por Fernando IV, en que lo reconoce como "mi vassallo hermano de don Gonçalo Arçobispo de Toledo". 1300, junio 15, Valladolid. Edit. Gonzalo Argote DE Molina, Nobleza... pp. 353-355. El segundo es de 1305, relacionado con una compra de tierras que realizó Pedro Díaz en Bailén y Baeza, donde él mismo se identifica como "hermano del arçobispo de Toledo". 1305, octubre, 3. Baeza. Archivo Histórico de la Nobleza (en adelante AHNOB), Baena, Cp. 1, D. 13. El tercero
} 
a varios autores dudar de la veracidad de los datos que transmiten los genealogistas, considerando algunos que el título de adelantado de Cazorla sólo se empezó a utilizar a partir de 1331, momento en que Quesada, que hasta entonces se consideraba una pieza clave en las propiedades del arzobispo de Toledo, fue entregada a Úbeda y Cazorla se convirtió en el centro más importante del señorío ${ }^{13}$. De hecho, el primer adelantado documentado es Sancho Rodríguez de Funes ${ }^{14}$.

Sorprende realmente que, si Pedro Díaz de Toledo fue adelantado de Cazorla, en ningún documento se haga referencia a ello, especialmente considerando que son tres documentos con fechas distintas los que se conservan y que éstos abarcan varios años del gobierno de Gonzalo Díaz (1300, 1305 y 1310), por lo que es igualmente extraño que en ninguna de esas fechas tuviera ese cargo. Sin embargo, ello es posible y podría haber ocupado el puesto por un periodo tan limitado que no hubiera coincidido con ninguna de los tres momentos indicados. Además, y como hemos visto, en 1287 existía el cargo de "adelantado de Quesada", y es posible que tras la pérdida de esta villa se cambiara el nombre por el de "adelantado de Cazorla". Está claro que el señorío del arzobispo de Toledo necesitaba un personal encargado de su administración, y perfectamente podía haber tenido este nombre, aunque igualmente podía haber desaparecido.

Todo esto me lleva a plantear varias posibilidades. Una, que efectivamente no fuera adelantado de Cazorla, y que los genealogistas confundieran este título con el de adelantado de Quesada, y de ahí que nunca aparezca como tal en la documentación. Otra, que Pedro Díaz de Toledo hubiera sido adelantado de Cazorla y que este cargo se hubiera creado tras la pérdida de la villa de Quesada, cuando Cazorla se convirtió en la villa principal del señorío. Que esto no fuera contemplado en la documentación conservada, podría ser debido a que hubiera poseído el oficio por un corto periodo de tiempo, o simplemente, e inexplicablemente, a que no se considerara que este dato fuera relevante.

En cualquier caso, e independientemente de que fuera o no adelantado de Cazorla, el arzobispo de Toledo lo debió de nombrar para importantes funciones administrativas del señorío de Cazorla y Quesada, especialmente militares, lo que puede explicar que, durante su gobierno estuviera implicado en numerosos hechos de armas, como la posible recuperación de Quesada, y en la construcción de una torre defensiva, origen del señorío de Santo Tomé.

Por otro lado, dos genealogías anónimas de la familia, conservadas en la colección Salazar y Castro, nos mencionan el control de la villa de Quesada por Pedro Díaz de

es el privilegio emitido por Gonzalo Díaz en que le autorizaba a construir una iglesia en Santo Tomé, y en él se indica "que vos Pero Díaz, nuestro hermano, fiziestes a seruiçio de Dios...". 1310, agosto, 13. AHNOB Baena, Cap. 6, doc. 3.

13 Juan de Mata CARriazo, Colección... pp. LXXVI-LXXX, piensa que no es probable que fuera adelantado de Cazorla ya este título no aparece ni en los citados documentos de 1300 y 1310. Por su parte, $\mathrm{M}^{\mathrm{a}}$ del Mar García Guzmán dice que el término "adelantado de Cazorla" sólo se empezó a utilizar a partir de 1331. Ma del Mar García Guzmán, El adelantamiento de Cazorla en la Baja Edad Media, Cádiz, 1985, pp. 148-150. 14 Aparece en un documento de 1332 en que actúa como representante de Cazorla en el pleito de términos que mantuvo con Quesada por términos. $\mathrm{M}^{\mathrm{a}}$ del Mar García Guzmán, El adelantamiento de Cazorla..., pp. $149-150$. 
Toledo $^{15}$, e incluso una de ellas indica que fue su alcaide "o por estar anexo la alcaidía al adelantamiento, o porque visto el valor de la persona del adelantado se dispuso que juntamente fuera alcaide"16. Es posible que con ello se aludiera a hechos anteriores a la conquista de esta plaza en 1295, y de este modo podríamos enlazar estos datos con los que nos dan los Milagros de Pedro Marín. Sin embargo, estas Genealogías se hacen eco también de su pérdida y de su posterior recuperación por parte de Pedro Díaz de Toledo. Así, las citadas crónicas nos relatan que, viéndose obligado a viajar, en su ausencia dejó a un sobrino suyo, de apellido Palomeque, como guardián de la villa, y que los moros de Guadix ${ }^{17}$ atacaron conquistándola. Debido a ello Pedro Díaz fue acusado de traición, por lo que para resarcirse promovió su reconquista, ayudándole para ello el propio arzobispo de Toledo, su hermano:

Sucedióle teniendo ambos ofizios que el rey Fernando el quarto lo lamase [sic] (algunos dicen que a las Cortes por el título de adelantado) con que siéndole preciso hacer ausencia dexó a un sobrino de apellido Palomeque por su lugartheniente en la alcaydía, y le tomó pleito omenaje de defender y de guardar la villa por el rey. Eran por alli muy frequentes las correrías de los moros de Granada y en esta ausencia del alcayde vinieron sobre Quesada grandes tropas y sitiando aquella villa la rindieron con gran pérdida de sus vezinos, lo qual sabido por el adelantado vino a ponerle cobro, y el rey se dio por ofendido del suceso haciendo cargo de la pérdida al arzobispo de Toledo por hermano del adelantado. $Y$ aunque se le dio lexítimo descargo con la forzosa ausencia y buen recado en que dexó la villa a un sobrino suyo hijodalgo de dar y recivir pleyto omenaje con que lo juramentó no se satisfizo el rey hasta que le llevasen las llaves de Quesada recobrada, o la caveza del mismo adelantado.

Por este grande empeño vino el arzobispo mesmo a la villa de Cazorla con muchos deudos, con amigos y con otras gentes conducidos. Y juntándose con su hermano el adelantado que tenía otras tropas prevenidas se hizo un sufiziente batallón para aquella empresa con que acometieron a Quesada, con tan grande esfuerzo que la entraron a escala vista, y en mui pocas horas la rindieron con muchos muertos moros. $Y$ del combate salió con tres heridas el adelantado porque con el mucho empeño de la función se entró como desesperado en lo más arriesgado y peligroso del combate, pero la victoria lo sañó más presto que la medicina. Puso luego buena e grande orden en la

15 El relato es más detallado en Genealogya de los cavalleros del apellido ylustre de Quesada... RAH, Colección Salazar, 09-00312 (D-37), fols. 57r-59v. Más resumido en Asçendençia de los señores de la cassa de Garçiez.... RAH, Col. Salazar, 09-00201 (B-92).

16 Genealogya de los cavalleros del apellido ylustre de Quesada... RAH, Colección Salazar, 09-00312 (D-37).

17 Especifica la procedencia de los musulmanes la Asçendençia de los señores de la cassa de Garçiez.... RAH, Col. Salazar, 09-00201 (B-92), fol. 184r. 
guarda de la villa y con su hermano el arzobispo envió las llaves de Quesada recobrada, pidiéndole licencia para llevarle él mismo su cabeza rendido a su servicio y a sus pies. Y satisfecho del adelantado el rey de sus buenos servicios y lo declaró por leal vasallo, dando licencia para comparecer en su real acatamiento.

Escarmentado así el adelantado dicen que se descidió de la alcaydía de Quesada y dexando la villa muy abastecida, municionada, guarnecida con que pudiera susistir y sustentarse se vido luego con el rey, y hechándose a sus pies le ofrezió su vida a su servicio y su caveza a su justicia si se le conociese alguna culpa en lo pasado, mas, constando en todo su ignocencia, el rey lo dio por libre de la instancia y lo declaró leal, seguro y fiel vasallo $y$ en lo admitió en su primera gracia y lo ocupó de nuebo en su servicio ${ }^{18}$.

Asimismo, en el privilegio de concesión del título de conde de Garcíez realizado en el siglo XVII, además de indicarse que fue el primer adelantado de Cazorla, se especifica que ganó por dos veces la villa de Quesada ${ }^{19}$, algo que tampoco consideramos improbable dada la inestabilidad de la zona y la importancia que se dio a estas acciones militares que justificaron el cambio del apellido familiar.

Es patente que, aprovechando la crisis castellana que se produjo a consecuencia de la muerte de Sancho IV y el inicio de la minoría de edad de Fernando IV, los nazaríes iniciaron a finales de 1295 una expedición siguiendo el curso del Guadiana Menor, llegando a asediar Quesada hasta su rendición e incorporación al reino de Granada ${ }^{20}$.

A partir de ese momento, y hasta 1310 la ambigüedad de la escasa información que tenemos es notable. Así, en la Historia de la Casa Real de Granada, se hace referencia a una conquista musulmana en $1299^{21}$, que Martín Jimena Jurado fecha en $1298^{22}$. Además, cuando en la Crónica de Fernando IV se habla de la pérdida por los

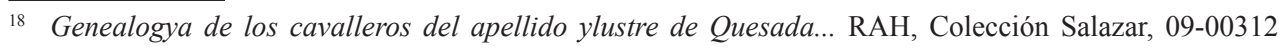
(D-37), fols. $57 \mathrm{r}-59 \mathrm{v}$.

19 1627, agosto, 16. Ed. Bartolomé Ximénez PAtón, Historia de la antigua y continuada nobleza de la ciudad de Iaén... fols. 174v-176r. Nos indica que Pedro Díaz de Toledo "fue el primer adelantado de Caçorla", y "porque por auer ganado los dichos vuestros ascendientes el Adelantamiento de Caçorla, y dos vezes la villa de Quesada, tomaron este apellido".

20 Así nos cuenta Ibn al-Jatib la victoria de Muhammad II: "En el mes de muharram del año 695 [=noviembre-diciembre 1295], a raíz de la muerte de Sancho, el tirano de los cristianos, hijo de Alfonso, se precipitó contra los infieles, mientras estaban consternados, reunió a los habitantes de al-Andalus, llamó a la lucha a los musulmanes y, aprovechando la ocasión que incitaba a ello, se puso en movimiento con un ejército grande y bien armado. Atacó la ciudad de Quesada y Dios la conquistó por medio de su mano. A causa de esto dominó el grupo de castillos que depende de ella, y fue muy grande la victoria". IBN AL-JATIB, Historia de los Reyes de la Alhambra, ed. de Emilio Molina, y José Ma Casciaro, Granada, 1998, p. 50.

${ }_{21}$ Historia de la Casa Real de Granada, ed. Juan de Mata CARriazo, En la frontera de Granada, Sevilla, 1971, I, p. 158.

22 Martín de Ximena Jurado, Catálogo de los Obispos de las Iglesias Catedrales de Jaén y Anales Eclesiásticos de este Obispado. Ed. J. Rodríguez Molina y Mª J. Osorio Pérez, Granada, 1991, p. 287. Año 1298. 
castellanos en 1302 de Bedmar "y otros castillos en derredor", es posible que Quesada fuera una de las plazas ocupadas ${ }^{23}$. Asimismo, algunos autores hablan, además de la conquista granadina de $1295-96$, de otra en $1303^{24}$. Por otro lado, y en base a un documento de exención del pago de la marzadga a los vecinos de Cazorla y sus aldeas de Toya, Dos Hermanas y Peal de Becerro, en el que no se incluye Quesada y sus aldeas, se puede suponer que en 1300 esta última villa no estaba en poder del arzobispo de Toledo ${ }^{25}$.

La inestabilidad de la frontera era un hecho y Quesada bien pudo recuperarse y perderse en sucesivas ocasiones, tanto antes como después de 1295, y Pedro Díaz de Toledo perfectamente podía haber estado implicado en algunos de esos hechos de armas. En cualquier caso, eran triunfos de breve duración, y Quesada se volvería a perder, hasta que en 1310 esta villa pasó definitivamente a manos cristianas, en virtud al acuerdo que se firmó entre Fernando IV y Nasr. Por él, el rey de Granada se comprometió a devolver las plazas de Quesada y Bedmar, además del pago de 50.000 doblas $^{26}$. Después de su recuperación, en 1311 Fernando IV volvió a donarla al arzobispo de Toledo ${ }^{27}$, bajo cuya jurisdicción permaneció hasta 1331, en que Alfonso XI la concedió al concejo de Úbeda ${ }^{28}$.

Otro problema que se nos plantea es el cambio de apellido de Toledo por el de Quesada. Los genealogistas atribuyen a Pedro Díaz de Toledo el cambio, denominándolo Pedro Díaz de Quesada, e incluso las dos genealogías conservadas en la colección Salazar y Castro explican ese cambio profusamente, relacionándolo con la recuperación de Quesada, e incluso una de ellas lo asocian a la vergüenza de mantener el apellido Palomeque por la falta de actitud de su sobrino, que trajo como consecuencia la pérdida de la villa. Por ello, Pedro Díaz solicitó al rey el cambio del apellido y armas, tomando el

23 Memorias del rey Don Fernando de Castilla, ed. Antonio Benavides, Madrid, 1860, vol. I, p. 99. Es lo que opina Juan de Mata CARriazo, Colección... p. 99.

24 Juan de Mata Carriazo, Colección... p. LXIX y Juan Francisco Rivera Recio, El Adelantamiento de Cazorla. Historia General. Toledo, 1948, p. 27. Así, Carriazo nos cuenta, siguiendo al biógrafo rondeño Mohamed-ben-Abdelrahman-ben-Abraim, que "el rey de Granada Abu Abdala (Mohamed III, desde 1302) le hizo general de un ejército enviado por la frontera del noroeste en 1303. Los granadinos pusieron sitio a la villa de Quesada y usaron para tomarla de una estratagema. Movieron su ejército de noche, simulando que huían, y cuando los cristianos, avisados por sus centinelas de esta maniobra, acudieron sin recelo a despojar el campamento abandonado, un grupo de moros que habían quedado en celada se apoderó de la plaza y atacó a los cristianos por la espalda".

25 Privilegio de 1300, julio 18. Edit. $\mathrm{M}^{\mathrm{a}}$ del Mar García Guzmán, Colección diplomática del Adelantamiento de Cazorla (1231-1495), Cádiz, 1991, doc. 28. Vid. Ma del Mar García Guzmán, "Santo Tomé y Pedro Díaz de Toledo. El origen de un linaje jiennense" El señorio de Cazorla en la Baja Edad Media ..., p. 193.

26 Crónica de don Fernando Cuarto, Crónicas de los reyes de Castilla, ed. Cayetano Rosell, Madrid, 1953, p. 165. Memorias del rey Don Fernando de Castilla, ed. Antonio Benavides, Madrid, 1860, vol. I, LXX.

27 1311, junio, 5. Juan de Mata Carriazo, Colección..., pp. 28-31.

28 1331, enero 22. Juan de Mata CARriazo, Colección..., pp. 31-35. A partir de ese momento se inició un largo pleito por la posesión de algunas de las aldeas de Quesada que ambos litigantes pretendían. Vid. M ${ }^{\mathrm{a}}$ del Mar García Guzmán, "Pleito y excomunión por cuestiones de términos entre Úbeda y Cazorla (siglo XV)". Estudios de historia y de arqueología medievales, 3-4 (1984), pp. 43-54. 
apellido Quesada por haber recuperado la villa y por armas veinticuatro armiños negros en cuatro bastones de plata en campo rojo, añadiendo como timbre en la parte superior el lema "potuis mori quam foedari"29.

Sin embargo, y a la vista de la documentación conservada, se puede comprobar que Pedro Díaz nunca utilizó el apellido Quesada, apareciendo siempre y hasta su muerte como Pedro Díaz de Toledo. De hecho, fueron sus descendientes los primeros que lo emplearon. Tan sólo se le asigna en un documento de 1354, muy posterior a su muerte (1328), redactado por sus nietos, que perfectamente pudieron equivocarse al estar consolidado por esas fechas el cambio ${ }^{30}$.

\subsection{El patrimonio de Pedro Díaz de Toledo}

A lo largo de su vida Pedro Díaz de Toledo fue acrecentando su patrimonio gracias a los beneficios que la Corona y el arzobispado de Toledo le concedieron debido al destacado papel en la lucha contra los nazaríes durante un momento tan complicado en la frontera granadina como fue el reinado de Fernando IV y la minoría de Alfonso XI, completándolo con otros bienes que fue adquiriendo en territorio jiennense.

De los beneficios regios tan sólo conocemos que en 1312 Fernando IV le donó las rentas de Muñera (Alcaraz) ${ }^{31}$. Por otro lado, su asentamiento en el reino de Jaén le llevó a adquirir algunas propiedades inmuebles en esta zona lo que le permitió consolidar su posición en este territorio. De hecho, en una fecha incierta de finales del siglo XIII, compró en término de Jaén la mitad de la torre de Domingo Peláez, mejorando la fortificación que debía existir "é que era a muy grand guarda é a muy gran pro del Concejo de la ciudad de Iahén, é de todos aquellos que andaban por la Campiña, é toda essa tierra". Por ello, en 1300 Pedro Díaz solicitó a Fernando IV la confirmación de esta compra, quien la autorizó "por muchos servicios que fizo al rey Sancho mio padre"32.

\footnotetext{
29 "Por lo qual, queriendo el adelantado sepultar del todo la memoria del sobrino, en cuio tiempo se perdió la villa sólo por apellidarse Palomeque, pidiendo apellido al rey y nuebas armas para fundar su casa a su posteridad, de donde resultó que tomase el apellido de Quesada, por haver restaurado aquella villa en que hizo más que si la restaurase, y por armas los veinte y quatro arminios negros en quatro bastones de plata en campo roxo, que por su madre le tocaban por el apellido Gudiel... siendo todo insignias a propósito del caso, porque la pureza de la plata, quando está azín dorada significa la de su lealtad, tan experimentada y comprovada entonces y los arminios que por limpios huyen con riesgo de la vida al lodo, significanse al riesgo de este cavallero por no manchar su mucha lealtad, y finalmente el campo roxo, diese testimonio de la sangre derramada por sus tres heridas con que restauró la villa de Quesada: a que en lo alto del escudo añadió un letrero: Potuis mori quam foedari: antes morir que mancharse, aludiendo a los armiños". Genealogya de los cavalleros del apellido ylustre de Quesada... RAH, Colección Salazar, 09-00312 (D-37), fols. 59v.

30 1453, abril 8. Toledo. Es una donación de los hijos de Fernando Díaz, y por lo tantos nietos de Pedro Díaz de Toledo, a su tío Día Sánchez de Quesada. AHNOB Baena, C. 102, D. 4.

31 1312, agosto 20. Cerco de Alcaudete. Gonzalo Argote de Molina, Nobleza.... pp. 371-372.

32 1300, junio 15, Valladolid. Según se indica en el documento, esta torre fue entregada por Fernando III a Adan Velaz, junto con 3 yugadas de heredamiento. Éste posteriormente la vendió a Domingo Peláez, y su mujer, doña María, finalmente a Pedro Díaz y a su mujer, Toda Roldán. Edit. Gonzalo Argote de Molina, Nobleza... pp. 353-355. También en RAH Colección Salazar, 09-00312 (D-37).
} 
La función principal de esta torre está descrita en el propio privilegio real. Se trataba de una pequeña fortificación destinada principalmente a la defensa esporádica de los labradores en caso de un ataque musulmán, como otras muchas que existían en la Campiña de Jaén, que se utilizaban además como almacenamiento de aperos agrícolas y cosechas recolectadas, por lo que son torres íntimamente ligadas al mundo agrario de la zona ${ }^{33}$. No obstante, algunas de ellas se convirtieron en base de pequeños señoríos que se crearon a partir de una torre o fortaleza construida en un cortijo, a la que los monarcas dotaban posteriormente de término en función de la importancia estratégica de la zona que defendían, próxima a la frontera. A continuación, y al calor defensivo de estas fortificaciones, se podían instalar pobladores, aunque no siempre era así. De hecho, si Pedro Díaz de Toledo tuvo en este caso la intencionalidad de asentar vecinos, como haría posteriormente en el heredamiento de Santo Tomé, ésta no fructificó.

Además de la torre de Domingo Peláez, en 1314 adquirió otras propiedades en término de Jaén, empleando para ello parte de la dote de su mujer ${ }^{34}$. Asimismo, sabemos que también tenía algunas propiedades en Mengíbar ${ }^{35}$.

Por otro lado, y dada su vinculación con el Adelantamiento de Cazorla, adquirió allí, no sabemos cómo ni cuándo, una heredad donde construyó una torre y un cortijo, a la que puso por nombre Santo Tomé, "porque tal día fueron los Moros vencidos en aquel lugar". En este caso, y a diferencia de la torre de Domingo Peláez, promovió su poblamiento con éxito. De hecho, su localización, en una zona relativamente llana, a las faldas de la sierra de Cazorla, en el valle del río Guadalquivir, obligaba a contar con las suficientes defensas como para poder poner en explotación sus tierras de labor y permitir el asentamiento de una población estable, lo que explica la importancia de la torre para salvaguardar a la población. Además, en 1310 su hermano Gonzalo Díaz Palomeque le concedió licencia para la construcción de una iglesia bajo la advocación de Santo Tomé, dándole a él y a sus descendientes el patronato sobre la misma ${ }^{36}$.

Todas estas circunstancias están detalladas en el privilegio que Gonzalo Díaz Palomeque dio a su hermano en 1310 para la construcción de la iglesia. En él se resaltaba la gran utilidad de esta torre, ya que era "un logar muy peligroso en tiempo de la guerra et en qual logar reçibió Dios muchos serviçios desque aquella torre fue fecha, en guisa que fue y grand cavalleria de moros desbaratados e vençidos por tres vezes e an escapado en aquella torre muchos christianos de muerte e de cautivazión" ${ }^{37}$.

\footnotetext{
33 Tomás Quesada Quesada, El paisaje de la Campiña de Jaén en la Baja Edad Media según los Libros de las dehesas, Jaén, 1994, pp. 42-43.

34 1314, abril 16. Berenguela Alfonso Correa y Juan García de Saavedra venden a Pedro Díaz la hacienda que tenían en Jaén. Para el pago Pedro Díaz empleó 12.500 mrs. que Pay Arias de Castro, señor de Espejo, le dio como dote a su sobrina Teresa Rodríguez de Biedma, mujer de Pedro Díaz (1314, el 16 de julio. Córdoba). Gonzalo Argote de Molina, Nobleza..., p. 375.

35 1322, febrero 3. Úbeda. Pedro Díaz de Toledo daba poder a su hijo Fernando Díaz para que cobrara las rentas que tenía en Mengíbar, Villarreal y Toledo. AHNOB Baena, C. 385.

36 AHNOB Baena, Carp. 6, doc. 3. Edit. Ma del Mar García Guzmán, "Santo Tomé y Pedro Díaz de Toledo...", pp. 206-208.

37 Idem.
} 
Don Gonzalo Díaz Palomeque estableció una serie de condiciones en ese patronazgo. Así, el patrono podría designar al clérigo que serviría en la iglesia de Santo Tomé, que debía de ser presentado ante el arzobispo, en caso de que éste estuviera en Andalucía, o ante el arcipreste de Quesada. Además, podría recaudar el diezmo de la heredad de Santo Tomé, "por la costa que tomastes en labrar aquel logar en serviçio de la Eglesia de Toledo e para mantenimiento de la fortaleza que fieziestes en tiempo de guerra", estableciendo que un tercio correspondería al clérigo de Santo Tomé, y los dos restantes a Pedro Díaz de Toledo y sus descendientes, con la obligación de pagar la soldada del sacristán y a proporcionar los ornamentos litúrgicos de la iglesia. Al mismo tiempo, se obliga a los patronos a pagar anualmente el día de Santo Tomé (3 de julio) media dobla de oro al arzobispo de Toledo en concepto de catedrático. Finalmente, el arzobispo de Toledo obligaba a Pedro Díaz de Toledo y sus descendientes a que "fagades guerra e paz a nos e a nuestros sucesores de la dicha torre", vinculado de este modo a los Quesada al arzobispo mediante un pleito homenaje ${ }^{38}$.

No obstante, y pese a la teórica subordinación de Santo Tomé al arzobispado de Toledo, los Quesada actuaron como señores con plena jurisdicción sobre la nueva villa, lo que provocó un largo enfrentamiento entre ambas partes, especialmente complicado en el siglo XV.

También en la zona de Cazorla fue propietario de las heredades de El Retamal y Villamontiel. Desconocemos cómo llegaron a su poder, ya que tan sólo tenemos referencia a ellas a partir del reparto de sus bienes entre sus herederos, efectuado en $1328^{39}$. De hecho, tanto El Retamal como Villamontiel habían pertenecido a la mesa arzobispal, y a fines del siglo XIII los prelados habían intentado incentivar su repoblación, por lo que Pedro Díaz de Toledo las pudo obtener bien por donación del arzobispo, bien por compra, o quizás por una conjunción de estas dos posibilidades ${ }^{40}$.

La tercera zona de acción de Pedro Díaz de Toledo fue el territorio de Baeza, donde, desde muy temprano empezó a tener bastantes intereses gracias, por un lado, a su matrimonio con doña Toda Roldán, por el cual controló la mitad de Garcíez adquiriendo posteriormente la otra mitad, como veremos más adelante, y por otro por sus actividades administrativas en el concejo de Baeza. Aunque no tenemos constancia de que adquiriera bienes en el término de Baeza, sí sabemos que obtuvo algunos inmuebles en su alfoz, y así, en 1305 compró a Alfonso y Sancha Ruiz, vecinos de Baeza, todas las heredades que tenían en Bailén, aldea de Baeza ${ }^{41}$. Fuera del reino de Jaén y Adelantamiento de Cazorla, debido a sus orígenes, tuvo además huertas, aceñas, casas y viñas en Toledo y Villarreal ${ }^{42}$.

\footnotetext{
38 Ma del Mar García Guzmán, "Santo Tomé y Pedro Díaz de Toledo...”, pp. 197-198.

39 1328, marzo 4. AHNOB Baena, C. 92, D. 34 y C. 178.

$40 \mathrm{M}^{\mathrm{a}}$ del Mar García Guzmán "Santo Tomé y Pedro Díaz de Toledo...”, pp. 203-4.

41 1305, octubre 3. Baeza. Alfonso Ruiz y Sancha Ruiz, vecinos de Baeza, venden a Pedro Díaz todas las heredades que tenían en Bailén, término de Baeza, por 1.250 mrs. AHNOB Baena, Carp. 1, D. 13.

42 1322, febrero 3. Úbeda. Pedro Díaz de Toledo daba poder a su hijo Fernando Díaz para que cobrara las rentas que tenía en Mengíbar, Villa Real y Toledo. AHNOB Baena, C. 385.
} 


\subsection{Las funciones administrativas en el concejo de Baeza}

Siguiendo la línea de actuación de otros miembros de la pequeña nobleza andaluza que hicieron de la vida en la frontera y de la ocupación de cargos municipales su forma de vida, Pedro Díaz de Toledo consiguió disfrutar de algunos oficios en el concejo de Baeza, abriendo el camino que sus descendientes continuarían a lo largo de la Baja Edad Media. De hecho, se avecindó en esta localidad ${ }^{43}$, adquiriendo en ella cierto protagonismo, ya que al menos en 1304 fue alcalde de Baeza ${ }^{44}$. Según establecía el Fuero de Baeza, este cargo era anual y de carácter electivo entre los vecinos de la localidad. La asamblea vecinal realizaba la elección de un alcalde por collación el primer domingo después de San Miguel (29 de septiembre). Su principal cometido era el ejercicio de la justicia ordinaria, actuando colegiadamente los viernes juntamente con el juez, que era la máxima autoridad política del concejo ${ }^{45}$.

Su vinculación con el concejo de Baeza permitió además que fuera el arrendador por seis años de los caminos que iban a Baeza, a condición de que mantuviera su alcázar. Sin embargo, en 1320 el concejo se quejó porque no había cumplido el acuerdo, ya que el edificio necesitaba numerosas obras de reparación, por lo que Alfonso XI le ordenó que realizara la rehabilitación, bajo amenaza de embargarlo ${ }^{46}$.

Además, durante el reinado de Alfonso XI ejerció como alcaide de Bélmez y Begíjar ${ }^{47}$. La tenencia de estos castillos le obligaba a asegurar y mantener una sólida y bien equipada guarnición, además de organizar un sistema básico e indispensable de vigilancia en ellos. Era un oficio preferentemente reservado a la clase nobiliaria, ya que era la más específicamente preparada para estas tareas ${ }^{48}$.

43 Genealogya de los cavalleros del apellido ylustre de Quesada... op. cit. RAH, Colección Salazar 0900312 (D-37), fol. 62r.

44 Es lo que nos indican el padre Francisco de Torres y una de las Genealogías conservadas en la colección Salazar y Castro. Así, el primero dice que en 1304 "fue llamado por todo el conçejo de Baeza para que fuesse su alcalde, que exerció este offiçio sin menoscabo de su nobleça" Historia de Baeza del P. Francisco Torres S.J. (1677). Ed. J. Rodríguez Molina, Jaén, 1999, p. 196. Algo muy parecido nos indica la Genealogya de los cavalleros del apellido ylustre de Quesada... op. cit. RAH, Colección Salazar 09-00312 (D-37), aunque sin dar la fecha exacta, apuntando tan sólo que fue alcalde de Baeza durante el reinado de Fernando IV.

45 Fuero de Baeza. Estudios Introductorios. Edición de Jean Roudil y facsímil (Coord. Ma . A. Carmona Ruiz.) Jaén, 2010, cap. 398 a 420, pp. 245-249.

46 1320, mayo 10. Valladolid. Archivo Histórico Municipal de Baeza (en adelante AHMB), 1/7/12. Edit. José Rodríguez Molina, Colección Documental del Archivo Municipal de Baeza, (En adelante Colección documental de Baeza) Jaén, 2002, doc. 40.

47 Al menos entre 1320 y 1322 lo era, como lo demuestra el documento de 1320, mayo 10. Valladolid. AHMB, 1/7/12. José Rodríguez Molina, Colección documental de Baeza, doc. 40 (Alfonso XI indica que era "mio alcaide de los castiellos de Belmes e de Bexixar") y 1322, febrero 13. Úbeda. AHNOB Baena, C. 385. (Poder de Pedro Díaz de Toledo, alcaide de Bélmez y Begíjar a su hijo Fernando Díaz).

48 Sobre el tema de la tenencia de fortalezas vid. $\mathrm{M}^{\mathrm{a}}$ Concepción Quintanilla Raso, "La tenencia de fortalezas en Castilla durante la Baja Edad Media”. En la España Medieval, (1986), pp. 861 y ss. y M ${ }^{\mathrm{a}}$ Concepción Castrillo Llamas, La tenencia de fortalezas en la Baja Edad Media. Relaciones de poder entre monarquí, nobleza y ciudades, Madrid, 1997 (tesis doctoral). 
Su creciente importancia en la zona explica que en la carta de Hermandad firmada en 1319 entre los concejos de Baeza y Úbeda para proteger los derechos de Alfonso XI se expresara la voluntad de ambos concejos de mantener las otras hermandades que habían firmado, entre las que se encuentran la establecida con Pedro Díaz ${ }^{49}$.

Considerando la vinculación que tuvo con Baeza, es muy probable que adquiriera algunos bienes en esta localidad. Desgraciadamente no se nos ha conservado su testamento, pero es posible que parte de su patrimonio tuviera que estar centrado en ella, especialmente considerando que estaba avecindado allí, requisito imprescindible para ejercer como alcalde ${ }^{50}$.

\subsection{Matrimonios y descendencia}

Pedro Díaz de Toledo se casó dos veces, enlaces que le reportaron importantes beneficios y valiosas relaciones con algunos miembros de la aristocracia andaluza. Así, contrajo matrimonio en primeras nupcias con doña Toda Roldán ${ }^{51}$, hija de Pedro Ponce de Cabrera, comendador de la orden de Santiago ${ }^{52}$, y en segundas con doña Teresa Rodríguez de Biedma, hija de Rodrigo Íñiguez de Biedma, caudillo de Jaén.

Respecto a doña Toda Roldán, algunos genealogistas erróneamente indican que esta señora se casó con Día Sánchez de Quesada, hijo de Pedro Díaz de Toledo ${ }^{53}$. Sin embargo, doña Toda Roldán aparece nombrada como mujer de Pedro Díaz de Toledo en la confirmación de la propiedad de la Torre de Domingo Peláez, efectuada por Fernando IV

49 1319, noviembre, 21. Baeza. "Et nos, los dichos conçeios, prometemos de guardare de tener todo lo que sobredicho es en esta carta, fasta que nuestro sennor el rey sea de edat, todavía guardando las hermandades que avemos con los del Arçobispado de Sevilla e con los obispados de Córdova e de Jahén, con nuestro sennor el obispo e con el maestre de Calatrava, e con Lope Ruiz, e Día Sánchez, e con Pedro Díaz, e Per Afan”. AHMB 1/1/1. Edit. José Rodríguez Molina, Colección Documental de Baeza, doc. 39.

50 Fuero de Baeza... op. cit. cap. 398, p. 245.

51 Así lo indican Francisco Ruano, Casa de Cabrera en Córdoba (1779, reed. Córdoba 1994). pp. 111 y ss. y Gonzalo Argote de Molina, Nobleza..., p. 360. Genealogya de los cavalleros del apellido ylustre de Quesada... op. cit. RAH, Colección Salazar 09-00312 (D-37), fol. 63v. Asçendençia de los señores de la cassa de Garçiez... op. cit. (B-92) fols. 181r-192v. Respecto al nombre y apellidos de esta señora, Francisco Ruano la denomina Thoda Pérez Roldán de Cabrera, mientras que Gonzalo Argote DE Molina, la llama Toda Pérez Roldán. Bartolomé Ximénez Patón y la Genealogya de los cavalleros... la denominan Toda Roldán de Sotomayor.

52 Fue Pedro Ponce de Cabrera comendador mayor de Castilla, de la orden de Santiago y fundador de la Casa de Cabrera de Córdoba, y de Toda Roldán de Alagón. Francisco Ruano Casa de Cabrera ... pp. 111 y ss.

53 Bartolomé Ximénez Patón, Historia de la antigua y continuada nobleza de la ciudad de Iaén... fol. 171v. Historia de Baeza del P. Francisco Torres... p. 196. Por su parte, López de Haro indica que Pedro Díaz se casó con Toda Roldán, y a su vez dice que su hijo Día Sánchez de Quesada tuvo matrimonio con Toda Pérez Roldán de Sotomayor. Alonso López De Haro, Nobiliario genealógico de los reyes y títulos de España, op. cit., fols. 552v-553r. 
en 1300 , lo que claramente muestra su relación ${ }^{54}$. Además, a través de este matrimonio entró a formar parte del patrimonio de los Quesada la mitad de la localidad de Garcíez.

Garcíez era un pequeño núcleo de población situado junto a una fortaleza, que tras su conquista en 1227 fue integrado en el alfoz de Baeza ${ }^{55}$. Sin embargo, debido a la expansión del adelantado de la frontera, Sancho Martínez de Jódar, por Sierra Mágina, esta villa entró a formar parte de su señorío, gracias a que en 1269 se la concedió Alfonso X, tras comprársela a Baeza, en agradecimiento a sus servicios militares en la frontera $^{56}$. A la muerte de don Sancho Martínez, ocurrida en 1274 ó 1275, su señorío se desintegró. Parte de estos dominios fueron recuperando por los musulmanes, mientras que otros los recibirían sus herederos o quedaron en manos de la corona ${ }^{57}$. El castillo de Garcíez pasó a poder de D. Ruy Pérez Ponce, maestre de Calatrava ${ }^{58}$, a quien, tras fallecer sin descendencia ${ }^{59}$, le sucedió en su posesión su hermano Pedro Ponce de Cabrera, comendador de la orden de Santiago ${ }^{60}$, que la dividió entre sus hijos Juan Ponce y Toda Pérez Roldán, llevando esta última su parte como dote al matrimonio con Pedro Díaz de Toledo ${ }^{61}$.

Posteriormente a la muerte de doña Toda ${ }^{62}$, Pedro Díaz de Toledo consiguió hacerse con la otra mitad de Garcíez, y así, en 1315 realizó un pleito homenaje, a través del cual Juan Ponce y su mujer Inés Enríquez de Harana, le entregaban su parte del castillo de Garcíez: "porque uos lo do bien e desenbargadamientre con todos sus donadios e con

\footnotetext{
54 1300, junio 15, Valladolid. Edit. Gonzalo Argote de Molina, Nobleza... pp. 353-355. También en RAH Colección Salazar, 09-00312 (D-37).

55 Así se puede ver en el privilegio de delimitación de los términos de Baeza dado por Fernando III en 1231, mayo 19. Burgos. AHMB 1/1/1. Edit. José Rodríguez Molina, Colección Documental de Baeza, doc. 1. Aunque no quede explícito en el en el documento, el término asignado a Baeza contenía un buen número de villas y aldeas, y entre ellas Garcíez. Se fijaban sus límites en el puerto de Muradal, el río Rumblar hasta el Guadalquivir y desde allí hasta Torres, que quedaba incluida, sierra de Bedmar y Jódar hasta Jandulilla, volviendo al Guadalquivir, los límites con Úbeda, Vilches, Santisteban, Torre de Albar y sierra de Muradal. 56 1269, marzo, 18. Jaén. Edit. Manuel GonZález JimÉneZ, Diplomatario andaluz Alfonso X, Sevilla, 1991, doc. 360 .

57 Sobre las vicisitudes del señorío de Sancho Martínez de Jódar Vid. Ma Antonia Carmona Ruiz, "Los avatares de un señorío de frontera en la Baja Edad Media. Jódar (Jaén) entre los siglos XIII y XV”, En la España Medieval, 39 (2017).

58 Francisco Ruano, Casa de Cabrera en Córdoba... p. 111.

59 Portvgalia Monumenta Historica... Livro dos linhagens do Conde D. Pedro. ed. José Mattoso, Lisboa, 1980, vol. II/2, Tit. LVIII, F (de E5), p. 100.

60 Ruy Pérez Ponce fue el decimoquinto maestre de Calatrava, cargo para el que fue elegido en 1284 . Francisco Rades y Andrada, Crónica de las tres Órdenes de Santiago, Calatrava y Alcántara, Toledo, 1572 (ed. facs. 1980), fols. 46v-48. Pedro Ponce fue comendador mayor de Castilla de la orden de Santiago, siendo maestre Pelay Pérez Correa, y fue el fundador de la Casa de Cabrera de Córdoba. Francisco Ruano, Casa de Cabrera en Córdoba... pp. 111-115. Salvador Moxó, "De la nobleza vieja a la nobleza nueva. Transformación nobiliaria castellana en la Baja Edad Media" Cuadernos de Historia (Anexos de la revista Hispania), 3 (1969), p. 125.

61 Francisco Ruano, Casa de Cabrera en Córdoba... p. 113.

62 No sabemos cuándo falleció Toda Roldán, pero debió que ser antes de 1314, fecha en que ya estaba casado con su segunda mujer.
} 
todas sus pertenençias" ${ }^{\prime 3}$. No tenemos constancia de ningún tipo de contraprestación por parte de Pedro Díaz de Toledo a cambio de esta donación.

Otra cuestión es determinar la descendencia del matrimonio entre Toda Roldán y Pedro Díaz de Toledo, ya que entre los genealogistas no hay acuerdo y no disponemos de documentación que nos lo aclare. Así, mientras que Argote de Molina afirmaba ignorar si tuvieron hijos, la mayor parte de las genealogías analizadas niegan que este matrimonio tuviera descendencia ${ }^{64}$, a excepción de la Genealogya de los cavalleros del apellido ylustre de Quesada, que indica que tanto doña Toda Roldán, como los hijos habidos en este matrimonio, perecieron al ser conquistada la villa de Quesada por los moros "y que así se averiguó y se supo quando al restaurar con toda brevedad la villa su marido la buscó" 65 . Por su parte F. Ruano, en su deseo de vincular a los señores de Garcíez y Santo Tomé critica todas estas ideas, arguyendo para ello, entre otras razones, que doña Toda aparecía nombrada en el documento de compra de la Torre de Domingo Peláez, que la mitad de Garcíez entra a formar parte del patrimonio de los Quesada a través de ella, y que una de las hija de Fernando Díaz -hijo de Pedro Díaz de Toledo y supuestamente de su segundo matrimonio- se llamaba Toda Roldán, por lo que no podía haber recibido este nombre si no hubiera sido nieta de su homónima ${ }^{66}$. Francisco Ruano no iba desencaminado, porque, efectivamente doña Toda Roldán tuvo descendencia, pero sin embargo ésta no fue la que finalmente formó el señorío de Garcíez, como veremos.

Así, entre la documentación conservada, tenemos un diploma de 1328 en el que se expresa la partición de Santo Tomé y Villamontiel entre los herederos de Pedro Díaz de Toledo. En el acto se dividieron estos bienes entre los herederos de doña Toda Roldán, y el resto de los hijos de Pedro Díaz de Toledo. Comparecieron, por una parte, Día Sánchez de Biedma, en representación de doña Teresa Rodríguez de Biedma y sus hijos -no se especifica sus nombres-, y por otra los hijos de doña Toda Roldán, o sus representantes: Perafán de Sotomayor ${ }^{67}$-en nombre de su mujer Teresa Sánchez-; Juan

\footnotetext{
63 1315, noviembre 28. Jaén. Archivo Histórico de Viana (en adelante AHV), caja 44, exp. 1b/Perg. Vid. Apéndice documental.

${ }_{64}$ Gonzalo Argote de Molina, Nobleza..., p. 360. Alonso López de Haro, Nobiliario genealógico... op. cit., fol. 553r. Bartolomé XImÉnez Patón, Historia de la antigua y continuada nobleza de la ciudad de Iaén..., fol. 171v. Asçendençia de los señores de la cassa de Garçiez... op. cit., RAH, Col. Salazar, 09-00201 (B92), fol. $181 \mathrm{r}-192 \mathrm{v}$.

${ }_{65}$ Genealogya de los cavalleros del apellido ylustre de Quesada... RAH, Colección Salazar 09-00312 (D37), fol. 65 r.

${ }^{66}$ Francisco Ruano, Casa de Cabrera en Córdoba... Casa de Cabrera en Córdoba, op. cit., p. 114. Hace referencia a un documento de 1354, abril 8, Toledo, en que los hijos de Fernán Díaz, Teresa Díaz, Toda Roldán y Diego, entregan a su tío Día Sánchez de Quesada los derechos que tenían en Garcíez, Villa Real, Santo Tomé, Mengíbar y Villamontiel. AHNOB Baena, C. 102, D.4. Este documento es también citado, aunque con fecha equivocada (8 de diciembre de 1354) por Gonzalo Argote de Molina, Nobleza..., p. 466.

67 Como bien indica Ma del Mar García Guzmán, en este documento sólo aparece citado como Per Afán, pero en otro de 1337, Teresa Sánchez se identifica como viuda de Per Afán de Sotomayor. AHNOB Baena, C. 235. Cfr. Ma del Mar García Guzmán, "Santo Tomé y Pedro Díaz de Toledo...", p. 199.
} 
Alfonso, en representación de María Díaz, -viuda de Gonzalo Díaz-, y de sus hijos; y Fernán Díaz. Así pues, los hijos de doña Toda Roldán y Pedro Díaz de Toledo fueron Teresa Sánchez, Gonzalo Díaz, fallecido antes de 1328, y Fernán Díaz ${ }^{68}$.

En lo que sí coinciden todas las genealogías es en el matrimonio de Pedro Díaz de Toledo con doña Teresa Rodríguez de Biedma. Ésta era hija de Rodrigo Íñiguez de Biedma, señor de Estiviel y caudillo de Jaén, y de doña Juana Díaz de Funes, hija del adelantado Día Sánchez de Funes, y sobrina de Payo Arias de Castro, señor de la villa de Espejo ${ }^{69}$. El enlace se debió de producir hacia 1314, ya que en esas fechas Pedro Díaz de Toledo empleaba los $12.500 \mathrm{mrs}$. que Payo Arias de Castro dio a su sobrina, posiblemente como dote, para comprar una hacienda en Jaén ${ }^{70}$.

Tenemos también bastantes problemas a la hora de dilucidar la descendencia del segundo matrimonio. Sólo conservamos un documento que hace referencia a la misma, el ya citado acuerdo de reparto de bienes entre los herederos de Pedro Díaz, en el que no se indica ni su número ni su nombre, aunque debemos suponer que fueron varios, ya que en él se dice que Día Sánchez de Biedma actuó en nombre "de su hermana Teresa Rodríguez e de sus fijos e del dicho Pedro Díaz" "'. Debemos suponer que, en esa fecha, 1328, eran menores de edad y por eso no intervinieron directamente en el acuerdo, puesto que, si el enlace entre Pedro Díaz y Teresa Rodríguez se produjo poco antes de 1314, como pensamos, el primogénito de este matrimonio no podía tener entonces más de 13 ó 14 años.

Por otro lado, no hay acuerdo entre los diferentes genealogistas y, de hecho, cometen errores manifiestos. Así, Argote sólo reconocía como único descendiente de este matrimonio a Día Sánchez de Quesada, algo que es erróneo, ya que, como he indicado, debieron tener varios hijos. Por su parte, la Genealogya de los cavalleros del apellido ylustre de Quesada, alude a dos hijos, Día Sánchez de Quesada y Fernando Díaz de Toledo, cuando sabemos que el segundo era hijo de doña Toda Roldán. Esto mismo

\footnotetext{
68 1328, marzo 4. Jaén. AHNOB Baena, C. 178. Otra copia de este documento en C. 92, D. 34.

69 Gonzalo Argote de Molina, Nobleza..., p. 375, Asçendençia de los señores de la cassa de Garçiez... op. cit., RAH, Col. Salazar, 09-00201 (B-92), fols. 181r-192v. Bartolomé XimÉnez PatóN, Historia de la antigua y continuada nobleza de la ciudad de Iaén..., fol. 171v. Rodrigo Íñiguez de Biedma, además de señor de Estiviel era caudillo de Jaén y alcalde de los alcázares de Jaén. Día Sánchez de Funes, o Fines, fue adelantado mayor de la frontera entre 1258 y 1261. Sobre el adelantado Día Sánchez de Funes, vid. Braulio VÁzquez CAmpos, Los adelantados mayores de La Frontera o Andalucía (siglos XIII-XIV). Sevilla, 2006, pp. 96-103. Payo Arias de Castro, además de señor de Espejo era alcalde mayor y alcaide del alcázar de Córdoba. Vid. Emilio Cabrera MuÑoz, "Orígenes del señorío de Espejo y la formación de su patrimonio territorial (1297-1319)". En la España Medieval. II. Estudios dedicados en memoria del profesor don Salvador de Moxó, Madrid, 1982, tomo I, pp. 211-231.

70 Según Gonzalo Argote, la compra de una hacienda a Berenguela Alfonso Correa y Juan García Saavedra se realizó el 16 de abril de 1314. El 16 de julio de ese año Payo Arias de Castro entregaba 12.500 mrs. (sin indicar en concepto de qué) para Teresa Rodríguez de Biedma, que Pedro Díaz empleó a pagar la citada hacienda. Gonzalo Argote de Molina, Nobleza... p. 375. Por su parte, Alonso López de Haro, Nobiliario genealógico..., op. cit., fol. 553r. y la Genealogya de los cavalleros del apellido ylustre de Quesada... indican que ese dinero era parte de la dote de Teresa Rodríguez.
}

71 1328, marzo 4. Jaén. AHNOB Baena, C. 178. 
indica Alonso López de Haro, añadiendo a Día Sánchez de Quesada y a Fernando Díaz de Toledo, a Toda Roldán, que, como sabemos, era la primera mujer de Pedro Díaz. Por otro lado, la Asçendençia de los señores de la cassa de Garçiez, incluye, además de a Día Sánchez de Quesada, a Teresa Sánchez, a Gonzalo Díaz y a Fernando Díaz de Quesada, cuando estos tres últimos eran hijos de doña Toda Roldán. Finalmente, Bartolomé Ximénez Patón, piensa que los hijos de este matrimonio fueron Día Sánchez de Quesada, Ponce Díaz de Quesada y Juana de Quesada. De Ponce Díaz de Quesada dice que fue caballero de la orden de Calatrava y maestresala de Pedro I, quien lo mató en Aguilar junto a otros caballeros por sospechas. De Juana de Quesada tan sólo indica que se casó con don Beltrán de Guevara, pero realmente ésta era su biznieta, ya que era hija de su nieto Pedro Díaz de Quesada ${ }^{72}$. Respecto a Ponce Díaz de Quesada, no tenemos clara su filiación, ya que otros autores, como Argote de Molina y López de Haro lo consideran hijo de Día Sánchez de Quesada y que Pedro I lo mandó matar en 1353 en el castillo de Aguilar ${ }^{73}$. Considerando que en 1328 Día Sánchez de Quesada debía ser menor de edad, pienso que, si Ponce Díaz de Quesada era hijo de éste, en 1353 debía ser demasiado joven para significarse tanto en la revuelta nobiliaria contra el rey.

Asimismo, sólo tenemos la seguridad de que Día Sánchez de Quesada era hijo de Pedro Díaz de Toledo y Teresa Rodríguez de Biedma y que, aunque debieron tener más hijos, no sabemos a ciencia cierta quiénes fueron, aunque es muy probable que uno de ellos fuera el citado Ponce de Quesada.

Pedro Díaz de Toledo debió morir poco antes de marzo de 1328, ya que fue en esa fecha cuando se produjo la avenencia entre sus herederos para repartir los bienes que había dejado en el adelantamiento de Cazorla. En este documento se establecieron dos partes, una que pasó a los descendientes del primer matrimonio, a los cuales le correspondió la heredad de Villamontiel, mientras que Santo Tomé, junto a El Retamal, pasaron a formar parte del patrimonio de los hijos de doña Teresa Rodríguez de Biedma ${ }^{74}$. Del reparto del resto de sus propiedades sabemos poco, y así, un documento de 1354 nos informa que los hijos de Fernando Díaz, descendiente del primer matrimonio de Pedro Díaz de Toledo, habían heredado propiedades en Garcíez, Villarreal, Santo Tomé, Mengíbar y Villamontiel ${ }^{75}$. Es probable que el acuerdo establecido en 1328 no se cumpliera, de ahí que los herederos de Fernando Díaz tuvieran bienes en Santo Tomé, aunque siempre existe la posibilidad de que éste las comprara posteriormente. Del mismo modo, debemos destacar que en este acuerdo no aparece registrado todo su patrimonio, caso

\footnotetext{
$72 C$ fr. $\mathrm{M}^{\mathrm{a}}$ Antonia Carmona Ruz, "Los Quesada, señores de Garcíez y Santo Tomé (Jaén) durante la dinastía Trastámara". Espacio Tiempo y Forma, 28 (2015), p. 164.

73 Gonzalo Argote de Molina, Nobleza... pp. 360 y 466. Alonso López de Haro, Nobiliario genealógico, fol. 55r. Pedro López de Ayala narra su muerte. Pedro LóPez de Ayala, Crónicas. Ed. José Luis Martín, Barcelona, 1991, p. 64. "E mataron ese día a Pero Coronel, sobrino de don Alfonso Ferrández, e a Juan González de Deza, e a Ponce Díaz de Quesada, e a Rodrigo Íniguez de Biedma”.

74 1328, marzo 4. Jaén. AHNOB Baena, C. 178. Otra copia de este documento en C. 92, D. 34.

75 1354, abril, 8. Toledo. Carta de donación de Teresa Díaz, Toda Roldán y Diego, hijos de Fernando Díaz los derechos que tenía en Garcíez, Villarreal, Mengíbar y Villamontiel. AHNOB Baena, C. 102, D.4.
} 
de Garcíez, la torre de Domingo Peláez, u otras heredades que Pedro Díaz de Toledo fue adquiriendo a lo largo de su vida. No sabemos cómo se repartió su herencia, pero lo que está claro es que la hacienda de Pedro Díaz se fraccionó entre sus hijos, por lo que Día Sánchez de Quesada tuvo que hacer una importante labor de reagrupamiento de parte sus bienes.

\section{Día Sánchez de Quesada I (1328-fns. S. XIV)}

Hemos visto cómo fue Pedro Díaz de Toledo el que consiguió tener cierta preminencia tanto desde el punto de vista político como territorial en el reino de Jaén. Sin embargo, sería su hijo Día Sánchez quien logró consolidar la posición de esta familia, convirtiéndola en una de las más influyentes de la zona. Fue el primero que utilizó el apellido Quesada, vinculándolo a un hecho de armas -real o ficticio- atribuido a su padre. Seguía la costumbre de algunos linajes de la zona ${ }^{76}$, dándole a la conquista de Quesada la suficiente importancia como para que permitiera el cambio de apellido y blasón de armas. Con ello mostraba su deseo de separación de sus ancestros, creando un linaje nuevo, utilizando para ello a un personaje -en este caso su padre- considerado glorioso por su actividad militar. Lo interesante es que como apellido fijo que se transmite a los herederos no utilizaron un topónimo relacionado con algunas de sus propiedades, como era lo habitual ${ }^{77}$, sino que emplearon un topónimo relacionado con una batalla, queriendo de este modo encumbrar el valor guerrero de la familia. Desconocemos si fue el propio Día Sánchez de Quesada el que hizo el cambio de apellido, o fue su padre el que lo que instauró para sus herederos. Sin embargo, no lo utilizaron todos sus descendientes, ya que los hijos del matrimonio entre Pedro Díaz de Toledo y doña Toda Roldán no lo tuvieron. Tan sólo tenemos constancia que lo usaron Día Sánchez de Quesada y Ponce Díaz de Quesada, y de este último no tenemos clara la filiación.

Al igual que en el caso de su padre, sabemos poco de la vida de Día Sánchez de Quesada, especialmente debido a la escasa documentación que se nos ha conservado. Analizándola podemos constatar que no era el primogénito de Pedro Díaz de Toledo, puesto que fue fruto de su segundo matrimonio con Teresa Rodríguez de Biedma y tampoco sabemos si era el hijo mayor de este enlace. Posiblemente recibió el nombre de Día Sánchez de su bisabuelo materno, Día Sánchez de Funes. Además, a la muerte de su padre debía de ser menor de edad, lo que explica que no estuviera presente en el convenio firmado en 1328 entre sus herederos. En cualquier caso, a través de los datos que he podido recopilar, se puede ver que a lo largo de su vida desarrolló dos

\footnotetext{
76 En el caso del Reino de Jaén tenemos algunos otros casos, como como es el caso de Sancho Martínez de Jódar, por ser el conquistador de esta villa, o, Día Sánchez de Funes, o Fines, llamado así porque ganó el castillo de Fines, cerca de Valporchena. Gonzalo Argote de Molina, Nobleza..., op. cit., p. 282.

77 Isabel Beceiro Pita y Ricardo Córdoba de La Llave, Parentesco, poder y mentalidad. La nobleza castellana, siglos XII-XV, Madrid, 1990, p. 63.
} 
facetas: una importante actividad política vinculada a Pedro I y la consolidación de un patrimonio señorial potente basado en la herencia de su padre con el que dar prestigio al linaje recién creado.

\subsection{La actividad política de Día Sánchez de Quesada}

Contamos con algunas las noticias que corroboran la vinculación de Día Sánchez de Quesada con la Corona. Ésta debió empezar durante el gobierno de Alfonso XI, pero fue especialmente patente en el reinado de Pedro I, de ahí que cuando este último le donó la aldea de Ibros indicara que lo hacía "por muchos servicios e buenos que fezistes al Rey Don Alonso mio padre, que Dios perdone, e fezistes, e fazedes a mi de cada dia"78. Buena parte de estos servicios debieron ser de carácter militar, lo que llevó al autor de la Genealogya de los cavalleros del apellido ylustre de Quesada a decir que fue "adelantado mayor de la frontera en el reino de Jaén contra los moros de Granada", defendiendo Baeza de los ataques nazaríes, e interviniendo como tal en la conquista de Algeciras ${ }^{79}$. Sin embargo, podemos constatar que en la toma de Algeciras de 1344 el adelantado de la frontera era don Juan Manuel, contribuyendo decisivamente a su conquista $^{80}$, y que las tropas jiennenses estaban encabezadas por Enrique Enríquez, caudillo del obispado de Jaén, que era el encargado de dirigir el ejército de este sector de la frontera ${ }^{81}$. No tenemos ninguna constancia documental de que Día Sánchez de Quesada ocupara el cargo de adelantado de la frontera, o alguno relacionado con él, como el de lugarteniente, por lo que es muy posible que fuera un error creado con la intención de buscar un mayor ensalzamiento del personaje.

Lo que sí está claro es la intervención de Día Sánchez de Quesada en algunas tareas de carácter político y diplomático al servicio de Pedro I. Así, al final de la Asçendençia de los señores de la cassa de Garçiez, se incluye una traducción de un documento -hoy desaparecido y escrito en latín-, en el que Pedro I nombraba a Día Sánchez de Quesada y a Garci Pérez de Valladolid ${ }^{82}$ para negociar el posible matrimonio de sus hijas Constanza e Isabel, y de Blanca, hija de don Fernando, "nuestra parienta", con los hijos legítimos del "ilustre y magnifico señor don Juan, conde de Armeniaco, nuestro amigo caríssimo" $"$.

\footnotetext{
78 Gonzalo Argote de Molina, Nobleza..., p. 467-469.

79 RAH, Colección Salazar 09-00312 (D-37).

80 Braulio VÁzquez Campos, Los adelantados mayores de La Frontera o Andalucía..., pp. 352 y ss.

81 Gonzalo Argote de Molina, Nobleza..., p. 445. Braulio Vázquez Campos, Los adelantados mayores de La Frontera o Andalucía..., pp. 350-351.

82 Garci Pérez de Valladolid fue desde 1352 alcalde del rey y oidor de su Audiencia. Luis Vicente Díaz Martín, "Sobre los orígenes de la Audiencia Real". HID, 2 (1994), pp. 125-308.

83 1357, julio 29. Sevilla. Al parecer era una carta escrita en latín de la cual se conserva una traducción en Asçendençia de los señores de la cassa de Garçiez..., op. cit. RAH, Colección Salazar, 09-00201 (B-92) f.181r-192v: "les damos poder para tratar y concertarse con el ilustre y magnifico señor don Juan, conde de Armeniaco, nuestro amigo caríssimo, o con sus tratadores o procuradores sobre las amistades temporales y perpetuas que an de haçer entre nos y el dicho, y entre nuestra casa y la suya y reçiprocos ausilios, que
} 
Este "conde de Armeniaco" no era otro que Juan I, conde de Armagnac, y el documento, suscrito el 29 de julio de 1357, era la respuesta a la delegación que el 2 de julio había enviado el conde de Armagnac con el fin de establecer una alianza con el monarca castellano ${ }^{84}$. Juan de Armagnac buscaba aliados en su enfrentamiento con el conde de Foix, Gastón III. Por su parte, Pedro I estaba inmerso en una guerra contra Aragón y le interesaba cualquier tipo de apoyo. Así pues, el acuerdo interesaba a ambas partes y se firmó poco después, en Sevilla el 19 de agosto. En él se dispuso un seguro mutuo en caso de guerra contra el conde de Foix, o los reyes de Aragón, Navarra o Inglaterra, así como el vasallaje de Juan de Armagnac a Pedro I. También se acordó el matrimonio de Blanca, hija del fallecido señor de Villena, Fernando Manuel, con uno de los hijos del conde ${ }^{85}$.

Por otro lado, y según nos relata la Crónica de Pedro López de Ayala, en 1358 fue uno de los caballeros encargado de custodiar en la Torre del Oro de Sevilla a Aldonza Coronel, mujer de Álvar Pérez de Guzmán y que era entonces amante del monarca castellano, mientras María de Padilla permanecía en el alcázar. A fin de proteger a doña Aldonza, Pedro I dio a sus cuidadores plenos poderes para actuar en caso de peligro, y creyendo éstos que los nuevos amores del rey suponían el abandono de María de Padilla, y por lo tanto el fin del valimiento de sus parientes, apresaron a Juan Fernández de Hinestrosa, uno de los hombres de confianza del rey y tío de doña María. Es posible que estos

en raçón desto se an de dar. Y ansí mismo sobre los desposorios y matrimonios que se an de haçer entre las carissimas mis hijas doña Costança, doña Isauel, doña Blanca, hija del señor don Fernando, nuestra parienta, y los ínclitos hijos legítimos del dicho conde de Arminiaco". El autor de esta crónica comete graves errores a la hora de interpretar el documento, diciendo: "poder que le da para las capitulaçiones de matrimonios entre la señora doña Costanza y doña Isauel, hijas del dicho rey don Pedro con dos hijos de Juan, conde arminiaco, duque de Lencastre que tubieron efecto, y también para sentar las capitulaçiones del casamiento del dicho rey con doña Blanca, hija del rey Fernando de Francia" (fols. 185v-186r). Debido a la homonimia identifica a Juan de Armagnac con Juan de Gante, duque de Lancaster, que se casaría en 1371 con la infanta Constanza. Del mismo modo confunde a Blanca de Villena con Blanca de Borbón, por lo que dice que a través de este acuerdo se estableció su matrimonio con Pedro I. Además, el rey de Francia no se llamaba Fernando, si no que era Juan II.

84 1357, julio 2. Manciet. La delegación estaba encabezada por Odet de Verdusan y Sancho de Beaulieu. Vid. Dominique BarroIs, Jean Ier, comte d'Armagnac, (1305-1373), son action et son monde. Tesis doctoral, Lille, 2004. (http://documents.univ-lille3.fr/files/pub/www/recherche/theses/barrois-dominique/html/ these.html. Consulta octubre 2014). M. BourBon, "Traité d'alliance offensive et défensive entre le roi de Castille Pierre le Cruel et le comte d'Armagnac", Revue des Sociétés savantes. Sixième série, tome VII, année $1878-1^{\mathrm{e}}$ trim., p. 59.

85 Juan I se reconoce vasallo del rey de Castilla, recibiendo una pensión anual de 1000 florines. A cambio él le aportaría un contingente de 250 hombres por 3 meses y una soldada de 10 florines al mes. Pedro I contribuiría con 80 soldados a costa de su aliado, especialmente en caso de guerra contra el conde de Foix o la villa de Toulouse vid. Dominique BARroIs, Jean Ier, comte d'Armagnac ..., nota 1147. Como vasallo del rey de Castilla Juan de Armagnac aparece en la lista de confirmantes del privilegio de donación de Ibros a Día Sánchez de Quesada. 1358, abril 14. Sevilla. Gonzalo Argote De Molina, Nobleza..., pp. 467-469. A consecuencia de este tratado Juan de Armagnac aportó tropas a Pedro I a partir de 1361. Dominique BARrois, Jean Ier, comte d'Armagnac... El posible matrimonio de Constanza e Isabel finalmente no se contempló, y Blanca de Villena, que entonces tenía sólo 10 años murió poco después, en 1361, y no llegó a casarse. Sobre el señorío de Villena en estas fechas vid. Aurelio Pretel Marín y Miguel Rodríguez Llopis, El señorio de Villena en el siglo XIV, Albacete, 1998, pp. 12-137. 
nobles aprovecharan el mandato de Pedro I para intentar deshacerse del valido real, que no parece que tuviera el apoyo de amplios sectores nobiliarios ${ }^{86}$.

Lo que está claro es que Día Sánchez de Quesada debió ser un personaje destacado en la corte de Pedro I. A consecuencia de ello en 1358 el monarca le donó la localidad de Ibros, aldea que hasta entonces había pertenecido al concejo de Baeza. Conocemos el privilegio gracias a la transcripción parcial que de él hizo Gonzalo Argote de Molina. En él básicamente se expresa la donación de esta aldea "por juro de heredad"87. Por su parte, Ximénez Patón dice que se la entregó por su matrimonio con doña Mayor Biedma $^{88}$. No podemos saber a través del texto que nos transmite Argote de Molina si lo que le donó Pedro I era el señorío pleno o tan sólo el territorial, dado que no lo transcribe completo, y de hecho únicamente indica "do vos Ybros (que es termino de Baeza) por juro de heredad para siempre jamas, etc.".

Al analizar esta donación son muchos los problemas que se nos plantean, especialmente cuando en el mes de septiembre de ese año el concejo de Baeza mandaba a Ferrán Sánchez, que prendara en bienes a "los vezinos del sennorio de Ibros" por las soldadas que les tocaba pagar "por los bienes que tienen en el dicho lugar de Ibros en el nuestro termino e sennorio" $"$. Estas palabras ponen de manifiesto la existencia de dos jurisdicciones en Ibros, y que una de ellas pertenecía a la ciudad de Baeza, lo que nos lleva a preguntarnos si realmente Pedro I entregó o no la totalidad de la aldea a Día Sánchez, y en caso de que se la donara totalmente, si hubo alguna resistencia por parte de Baeza a la hora de deshacerse de su aldea, y por eso Día Sánchez sólo pudo disfrutar de la mitad. Desgraciadamente, debido a la falta de precisión del texto, que en parte se puede deber a que Argote no transcribió los párrafos en que se indicaba la proporción de la donación, no podemos llegar a ningún tipo de conclusión. Lo que sí está claro es que en fechas posteriores Ibros estaba dividida en dos jurisdicciones, una de las cuales pertenecía a Baeza ${ }^{90}$.

Algunos genealogistas, como López de Haro, o el autor de la Genealogya de los cavalleros del apellido ylustre de Quesada indican que Pedro I le donó también la villa

\footnotetext{
86 Los nobles que estuvieron implicados en este asunto fueron Pedro Fernández de Velasco, Suero Pérez de Quiñones y Día Sánchez de Quesada. Pedro LóPez de Ayala, Crónicas, op. cit., pp. 184-186. Luis Vicente Díaz Martín, Pedro I el Cruel (1350-1369). 2007², pp. 157-158. Sobre doña Aldonza Coronel, vid. Laureano Rodríguez LiáÑez, “Aldonza Coronel esposa de dos Álvar Pérez de Guzmán”. HID, 31 (2004), pp. 559-572.

87 1358, abril 14. Sevilla. Gonzalo Argote de Molina, Nobleza..., pp. 467-469.

88 "Casó el dicho Día Sánchez con doña Mayor de Biedma su prima, hija de Día Sánchez de Biedma y de doña Alfonso [Godínez]... para cuyo casamiento el señor rey don Pedro hizo merced de la villa de Ibros". Bartolomé Ximénez PATón, Historia de la antigua y continuada nobleza de la ciudad de Iaén... fols. 171v-172r.

89 1358, septiembre 6. Baeza. AHMB 1/15/60. Edit. José Rodríguez Molina, Colección Documental de Baeza, doc. 134.

90 Sobre este tema vid. $\mathrm{M}^{\mathrm{a}}$ Antonia CARmona Ruz, "Nuevos datos sobre el proceso de señorialización de Andalucía: la evolución del señorío Ibros (Jaén) entre los siglos XIV y XV". Historia y genealogía, 4, Córdoba, 2014, pp. 133-150. http://www.historiaygenealogia.com/index.php/hyg/article/view/84/52.
} 
de Zuca (o Zula), situada en el término de la ciudad de Baeza ${ }^{91}$. No tenemos más referencias a esto ni tampoco constancia de este topónimo en la zona. Por su parte, Pedro Gerónimo de Aponte nos comenta que el rey le donó además de Ibros las villas de Lezuza y Munuera ${ }^{92}$.

La guerra civil castellana y la muerte de Pedro I le tuvieron que acarrear importantes problemas debido a su vinculación con este monarca. Así, y según nos cuenta la Genealogya de los cavalleros del apellido ylustre de Quesada, perdió Ibros y Zula, mientras que Aponte indica que además de ser despojado de Ibros, perdió las villas de Lezuza y Munuera ${ }^{93}$. Posteriormente tuvo que huir a Portugal, volviendo posteriormente, "teniendo que contentarse con las haciendas heredadas y compradas"94. Seguramente fue uno de los muchos petristas, que después de la muerte del monarca fueron a Portugal con la intención de convencer a Fernando I para que reclamara el trono castellano ${ }^{95}$, lo que provocó una guerra que se solucionó con la paz de Alcoutim de 1371, en la que se perdonó a los partidarios de Pedro I aunque sin ningún tipo de indemnizaciones ${ }^{96}$. Efectivamente tuvo que ser así, ya que estas villas desaparecieron del patrimonio de los Quesada ${ }^{97}$. En cualquier caso, resulta curioso que tan sólo se les quitaran las donaciones de Pedro I, y no se le embargara todo el patrimonio, como ocurrió a otros muchos emperegilados y petristas, lo que puede ser indicio de su poca relevancia en el proceso.

\subsection{El patrimonio de Día Sánchez de Quesada}

Un segundo aspecto que ocupó la vida de Día Sánchez de Quesada fue la creación de un patrimonio territorial, del que Ibros era tan sólo una parte. Así, teniendo como base la herencia de su padre, su principal preocupación fue intentar recomponer su hacienda. Desconocemos qué fue lo que Día Sánchez de Toledo heredó. Es posible que al menos recibiera parte de Santo Tomé, si se cumplió el acuerdo de 1328, y no sabemos si obtuvo alguna parte de Garcíez, o del resto de las propiedades que tenía Pedro Díaz de Toledo. En cualquier caso, y a la vista de la información que disponemos, podemos afirmar que debió conseguir rehacer buena parte del patrimonio paterno. Tenemos tres documentos que avalan esto.

\footnotetext{
91 Zuca, según Alonso LóPEZ de HARO, Nobiliario genealógico... fol. 553r. Lo recoge posteriormente como Zula la Genealogya de los cavalleros del apellido ylustre de Quesada..., RAH, Colección Salazar 09-00312 (D-37).

92 Pedro Gerónimo de Aponte, Lucero de la Nobleza, s. XVII. BNE, Ms. 3074, fol. 315v.

93 Pedro Gerónimo de Aponte, Lucero de la Nobleza..., fol. 315v.

94 Genealogya de los cavalleros del apellido ylustre de Quesada..., op. cit., fols. 73r-v.

95 Fátima Regina Fernandes, "Os exilados castellanos no reinado de Fernando I de Portugal”, En la España Medieval, 23, (2000), pp. 101-115. Covadonga Valdaliso, "El exilio político de los pretistas en Portugal (1369-1373)", Erasmo. Revista de Historia Bajomedieval y Moderna, 1 (2014), pp. 152-168.

96 Luis Suárez Fernández, "La Guerra civil" en Historia de España de Ramón Menéndez Pidal. XIV, La crisis de la reconquista (c.1350-c.1410). Madrid, 1991, pp. 134-148.

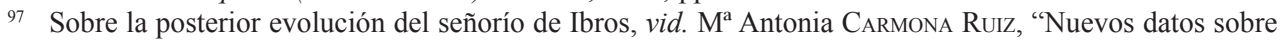
el proceso de señorialización...”.
} 
Por un lado, se conserva un texto de 1354 en el que se expresa la donación de Teresa Díaz, Toda Roldán y Diego, -hijos de Fernando Díaz, y por lo tanto, sobrinos de Día Sánchez de Quesada- de los derechos que tenían en Garcíez, Villarreal, Santo Tomé, Mengíbar y Villamontiel. En él se expresa específicamente que esta entrega se hacía sin ningún tipo de contrapartida ${ }^{98}$.

Por otro lado, tenemos dos documentos fechados en 1358 en los que aparece como propietaria de una parte de Garcíez una tal Urraca Pérez, viuda de Fernando Rodríguez de Sotomayor y sobrina de Día Sánchez de Quesada. Es difícil identificar quién era esta Urraca Pérez, pero, considerando que Garcíez se debió de repartir entre los herederos de Pedro Díaz de Toledo, y sabiendo que una de sus hijas, Teresa Sánchez, se había casado con Perafán de Sotomayor ${ }^{99}$, podemos suponer que un descendiente suyo podría haber sido Fernando Rodríguez de Sotomayor, y que su viuda fuera Urraca Pérez. Siguiendo esta hipótesis, ésta habría heredado los bienes de su marido, entre los que se encontraba una parte de Garcíez, que Día Sánchez de Quesada tenía gran interés en poseer.

Por ello, sabiendo que doña Urraca Pérez se encontraba en el monasterio de San Clemente de Sevilla gravemente enferma, debió concertar con ella un encuentro. Es muy posible que doña Urraca no tuviera descendientes directos, de ahí que Día Sánchez intentara conseguir que ésta le cediera su parte de Garcíez.

El primero de los documentos relacionados con esto es un testimonio elaborado por Diego González, escribano público de Sevilla, de la entrevista que tuvo lugar el lunes 16 de abril de 1358, a hora nona, entre Urraca Pérez y Día Sánchez de Quesada. La reunión se llevó a cabo en las habitaciones de la abadesa del monasterio de San Clemente, y allí se expuso la existencia de un pleito por la propiedad de Garcíez, y que éste se había resuelto con un acuerdo firmado ante el escribano de Sevilla Gonzalo Martínez, en que se había estipulado que al fallecimiento de doña Urraca, Pedro Díaz de Quesada, hijo de Día Sánchez, recibiría en herencia "la parte e sennorío e heredat que ella auía en el dicho castiello de Garçiez". Por ello Día Sánchez planteó a la enferma la posibilidad de que "tomase por ella pleito e omenaje a Gil Ruyz de Villaseca que y estaua presente para que touiese el dicho castiello por ella para gelo diese e gelo entregase cada que lo demandare". Sin embargo, doña Urraca dijo que prefería dejarlo para el miércoles "et que él que veniesse a ella e que le plazía de fazer todo lo quel dicho Día Sánchez quisiese"100.

El segundo documento se suscribió en casa de García Alfonso Triguero, alcalde de corte, una semana después, el 23 de abril, ante el escribano público de Sevilla Gonzalo Martínez, recogiéndose la declaración jurada de varios de los testigos que estuvieron en una entrevista que sostuvieron Día Sánchez de Quesada y Urraca Pérez, que, según indican,

\footnotetext{
98 1354, abril 8, Toledo. AHNOB Baena, C. 102, D.4.

99 En 1337, ya viuda de Perafán de Sotomayor, carga una copia de la donación del privilegio de donación de Mengíbar a Sancho Pérez Pedralt (1249, mayo 19). AHNOB Baena, C. 235.

100 1358, abril 16. Sevilla. AHV, caja 44, Exp. 1c/Perg.
} 
se celebró el 16 de abril a hora de vísperas. Así, Día Sánchez de Quesada exponía que ambos habían mantenido un pleito ante Domingo Juan, alcalde de corte, relacionado con la propiedad de Garcíez, pero que antes de que éste concluyera, doña Urraca había fallecido. Antes de morir había hecho un codicilo "ante testigos rogados, porque diz que no pudo auer para esta sazón escriuanos públicos para lo otorgar ante ellos", por el cual legaba a Día Sánchez de Quesada su parte de Garcíez. Dado que muchos de los testigos se habían marchado, y otros se podían ir, ante el riesgo de perder el derecho del codicilo, Día Sánchez pedía que el alcalde García Alfonso recibiese juramento y testimonio de los que aún estaban en la ciudad. Por ello, se recoge la declaración de cuatro $^{101}$ que básicamente expresaron lo mismo: Que habían acudido al monasterio de San Clemente junto a Día Sánchez de Quesada el 16 de abril a hora de vísperas, y que se encontraron con doña Urraca que estaba en cama, y que Día Sánchez de Quesada manifestó su voluntad de que Gil Ruiz de Villaseca hiciera pleito homenaje a ella por todo el castillo, y que en relación al litigio que tenían pendiente, aceptaba lo que ella quisiera. A cambio Urraca Pérez manifestó su voluntad de dejarle todo lo que tenía en Garcíez tras su muerte ${ }^{102}$.

Así pues, y a la vista de estos dos textos, podemos afirmar que Día Sánchez de Quesada quería conseguir la parte que de Garcíez tenía Urraca Pérez y que ambos habían iniciado un pleito ante Domingo Juan, alcalde de corte. Desconocemos las razones exactas de este litigio, pero lo que sí está claro es que sin haber concluido aún, doña Urraca había enfermado gravemente, y que Día Sánchez había logrado que ésta dejara en herencia su parte de Garcíez a su hijo Pedro Díaz de Quesada. Sin embargo, lo que pretendía era ser él mismo el propietario de la totalidad de la villa, de ahí que se entrevistara con su sobrina en el monasterio de San Clemente de Sevilla, donde estaba enferma, intentando convencerla para que cambiara de opinión, por lo que accedía incluso a que el alcaide le hiciera pleito homenaje únicamente a ella, admitiendo de este modo la pertenencia del castillo exclusivamente a doña Urraca, a cambio de que se lo dejara a él en herencia. Sin embargo, y pese a la ventajosa oferta, doña Urraca, posiblemente debido a su precario estado de salud, prefirió dejar el asunto para otro día. No obstante, y según se indica en el segundo documento, esa misma tarde hubo una segunda reunión en la que doña Urraca accedía a dejar su parte de Garcíez a Día Sánchez de Quesada.

Resulta, cuanto menos curioso, que mientras que en la primera entrevista había tres escribanos presentes, sin embargo, en la segunda no había ninguno. Posiblemente a lo largo del día se debió agravar el estado de salud de Urraca Pérez, por lo que Día Sánchez debió acudir apresuradamente y sin contar con ningún notario, de ahí que en esta ocasión la enferma lo recibiera en cama.

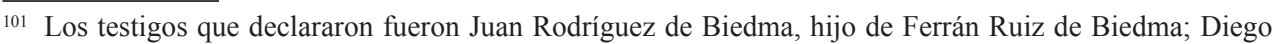
López de Porras, vecino de Sevilla; Gonzalo Martínez, de la cámara del rey; y Alfonso Fernández, criado de Lope García de Porras.

102 1358, abril 23. Sevilla. AHV, caja 130, Exp. 44/Perg.
} 
Se podría pensar que, ante su inesperada muerte, Día Sánchez intentara hacerse con su herencia presentando el falso testimonio de varias personas allegadas a él. Sin embargo, considerando que las Partidas obligaban a que estuvieran presentes cinco testigos ${ }^{103}$, y que él sólo presentó el testimonio de cuatro, si su intención era falsear la información, lo más lógico es que hubiera declarado una persona más. Seguramente decía la verdad, que en el momento de la declaración de doña Urraca había más testigos -al menos los cinco que estipulaban las Partidas-, y que éstos se habían ido de la ciudad. En cualquier caso, Día Sánchez de Quesada consiguió hacerse con la parte de Garcíez de su sobrina. Teniendo en cuenta que Día Sánchez de Quesada logró unificar las villas de Garcíez y Santo Tomé, y dada la fragmentación del patrimonio de Pedro Díaz de Toledo entre sus hijos, es posible que tuviera que negociar con el resto de los herederos la adquisición de algunos de sus bienes. Sin embargo, y ante la falta de documentación, ésta es sólo una mera hipótesis, ya que también es verosímil que sólo realizara acuerdos con los herederos de Fernando Díaz y con Urraca Pérez, y que sólo obtuviera lo que recibió de ellos. Lo que sí está claro es que la reunificación del patrimonio de su padre le tuvo que acarrear bastantes problemas, por lo que posiblemente con el fin de evitar conflictos posteriores, creó un mayorazgo con las villas de Santo Tomé y Garcíez. No conservamos el documento fundacional, sino tan sólo referencias posteriores. La más antigua se encuentra en el testamento de su hijo Pedro Díaz de Quesada, en que dejaba a su primogénito "el mayorazgo de Santo Tomé y Garcíez", que él heredó de su padre ${ }^{104}$.

Con todo, Día Sánchez consiguió además de ser dueño de Ibros, Santo Tomé y Garcíez, propiedades en Villarreal, Santo Tomé, Mengíbar y Villamontiel. Además, debió adquirir otros inmuebles, y así compró parte de las tierras que Ruy Fernández de Fuenmayor (o de los Escuderos) tenía en Jarafe, en Gil de Olid y en la ribera del Guadalimar ${ }^{105}$.

\subsection{Matrimonio y descendencia}

No está muy claro con quien contrajo matrimonio Día Sánchez de Quesada. Así, mientras que Gonzalo Argote de Molina no lo especifica, el resto de los genealogistas tampoco se ponen de acuerdo. De hecho, tanto Alonso López de Haro como Bartolomé Ximénez Patón, se hacen eco, equivocadamente, como hemos visto, de un primer matrimonio con Toda Roldán. En relación a las segundas nupcias, mientras que el primero ignora con quien las contrajo, Ximénez Patón dice que se casó con Mayor

\footnotetext{
103 "Departimiento ha muy grande entre los codicillos et los testamentos; ca los codicillos bien se pueden facer maguer non pongan en ellos seellos los que los facen nin los testigos que se hi acertaren, mas puédenlos facer ante cinco testigos." Las Siete Partidas del rey don Alfonso el Sabio, RAH, tomo III, Madrid, 1807, Partida VI, título 12, ley 3, p. 477.

104 1421, enero, 20. Baeza. AHNOB Baena, C. 82, D. 18.

105 Gonzalo Argote de Molina, Nobleza..., p. 485. Genealogya de los cavalleros del apellido ylustre de Quesada... RAH, Colección Salazar 09-00312 (D-37). Alonso LóPEZ DE HARO, Nobiliario genealógico..., fol. $553 \mathrm{r}$.
} 
de Biedma, prima suya, hija de Día Sánchez de Biedma y de doña María Alfonso Godínez $^{106}$, señores de Estiviel. Por su parte, la Genealogya de los cavalleros del apellido ylustre de Quesada hace referencia a un único matrimonio con Mayor de Biedma, mientras que la Asçendençia de los señores de la cassa de Garçiez, piensa que se desposó con Leonor de Biedma, y erróneamente comenta que era "hija de Martín Rodríguez de Biedma, señor de Santisteban”. Seguramente se refiriera a Men Rodríguez de Biedma, o Benavides, hijo de Día Sánchez de Biedma y que fue señor de Santisteban a partir de 1381.

Asimismo, tenemos problemas a la hora de dilucidar su sucesión, y en este sentido lo único que tenemos claro es que al menos tuvo un hijo, llamado Pedro Díaz de Quesada, y que según Ximénez Patón fue su único descendiente ${ }^{107}$. No obstante, y como hemos visto, otros autores, piensan que Ponce Díaz de Quesada fue también su hijo ${ }^{108}$. Si esto es así, debía ser muy joven en 1353, año en que murió en el castillo de Aguilar. Por otra parte, si es verdad que en 1358 Pedro I entregó a Día Sánchez de Quesada la villa de Ibros como dote por su matrimonio con Mayor de Biedma, según nos indica Ximénez Patón ${ }^{109}$, era imposible que Ponce Díaz de Quesada descendiera de este matrimonio, por ello, si aceptamos este dato, y consideramos que Ponce Díaz de Quesada era hijo de Día Sánchez, podríamos suponer que era ilegítimo, y lo debió tener muy joven. Así, y a la vista de los datos con que contamos, es difícil conocer cuál era la filiación de Ponce Día de Quesada. Lo que sí es evidente es que Juana de Quesada, que casó con Beltrán de Guevara, no fue fruto de este matrimonio, aunque así lo indique Argote de Molina $^{110}$. Por otro lado, al poner a su hijo el nombre de Pedro Díaz de Quesada, Día Sánchez de Quesada inició la costumbre de la alternancia del nombre Pedro Díaz / Día Sánchez en los primogénitos del linaje.

Día Sánchez de Quesada debió fallecer antes de finalizar el siglo XIV, y fue enterrado en la capilla mayor del convento de San Francisco de Baeza. Este convento fue sustituido a principios del siglo $\mathrm{XV}$ por otro cercano al primero y situado a extramuros de la ciudad. En 1403 sus frailes entregaron a su hijo, Pedro Díaz de Quesada, la nueva capilla mayor para colocar los restos de su padre y sus descendientes, como recompensa por las

\footnotetext{
106 Ximénez Patón dice erróneamente que éstos fueron señores de Santisteban, cuando quien recibió este señorío fue su hijo Men Rodríguez de Biedma, o de Benavides. Bartolomé XIMÉnEz PATÓN, Historia de la antigua y continuada nobleza de la ciudad de Iaén..., fol. 171v Cfr. $\mathrm{M}^{\mathrm{a}}$ Concepción Quintanilla Raso, “Aportación al estudio de la nobleza en la Edad Media: La casa señorial de Benavides". HID, 1 (1974), pp. $175-178$.

107 Bartolomé Ximénez Patón, Historia de la antigua y continuada nobleza de la ciudad de Iaén..., fol. 171v.

${ }_{108}$ Son de esta opinión A. López de Haro, G. Argote de Molina y el autor de la genealogía Asçendençia de los señores de la cassa de Garçiez...

109 Bartolomé XIMÉnez Patón, Historia de la antigua y continuada nobleza de la ciudad de Iaén..., fol. 171v. 110 Gonzalo Argote de Molina, Nobleza... p. 362 y Genealogya de los cavalleros del apellido ylustre de Quesada... RAH, Colección Salazar 09-00312 (D-37). Juana de Quesada fue hija de su hijo Pedro Díaz de Quesada.
} 
limosnas y mercedes que esta familia concedía al convento ${ }^{111}$. De hecho, fue el primer linaje de Baeza en asociar su fama póstuma a un edificio conventual, reservándose para ello el espacio más importante, la capilla mayor, a diferencia del resto de la nobleza baezana, que solía tener capillas funerarias en los principales templos intramuros de la ciudad, como la Catedral de Santa María, San Miguel y, especialmente, Santa María del Alcázar ${ }^{112}$. Su vinculación con la orden de San Francisco explica que, aunque no utilizaran este enterramiento, se sepultara con el hábito franciscano, costumbre que solían seguir otros miembros del linaje.

\section{Conclusiones}

A través de estas páginas hemos intentado realizar un exhaustivo análisis de los creadores del linaje de los Quesada a partir de la escasa documentación conservada. Como se puede comprobar responde al prototipo de la nobleza que se va a asentar en Andalucía y va a conseguir un notable protagonismo en la vida política, económica y social de la región. El prestigio militar de Pedro Díaz de Toledo lo convertirá en el pariente mayor del linaje, aunque fue su hijo, Día Sánchez de Quesada, quien conformó la conciencia de su existencia, a partir de la reconstrucción de buena parte del patrimonio paterno, convirtiéndose éste en la base territorial del linaje, y con el cambio el apellido familiar en base a una de sus acciones militares, como fue la conquista de Quesada.

Esta labor de conformación del linaje fue completada con una interesante política matrimonial, con la que conseguirán emparentar con otros linajes locales, integrándose en el grupo oligárquico de la ciudad de Baeza en cuyo gobierno participarían sus descendientes. Día Sánchez de Quesada desarrolló una notable actividad política al servicio de Pedro I, lo que le supuso también un incremento patrimonial y de prestigio. La muerte del monarca supuso el embargo de las donaciones del monarca, aunque no el desprestigio del linaje, ya que consiguió recuperar la ascendencia y el poder perdidos con la guerra civil y el ascenso de los Trastámara ${ }^{113}$.

\footnotetext{
111 1403, diciembre 3. Baeza. AHNOB Baena, Cp. 6, D. 5 y ARChGr. 738/011. Sobre las distintas ubicaciones y reformas del convento de San Francisco de Baeza vid. José Policarpo Cruz Cabrera, "El mecenazgo religioso como imagen del poder. La fundación de la capilla mayor del convento de San Francisco de Baeza". I Coloquio de iglesia y sociedad en Andalucía en la Edad Moderna. Granada, Universidad de Granada, (1999), pp. 409-424.

112 José Policarpo Cruz CABRera "El mecenazgo religioso ....".

${ }^{113}$ El estudio del linaje de los Quesada durante el siglo XV lo pueden consultar en $\mathrm{M}^{\mathrm{a}}$ Antonia Carmona Ruzz, “Los Quesada, señores de Garcíez y Santo Tomé (Jaén) durante la dinastía Trastámara”. Espacio Tiempo y Forma, 28 (2015), pp. 159-199.
} 


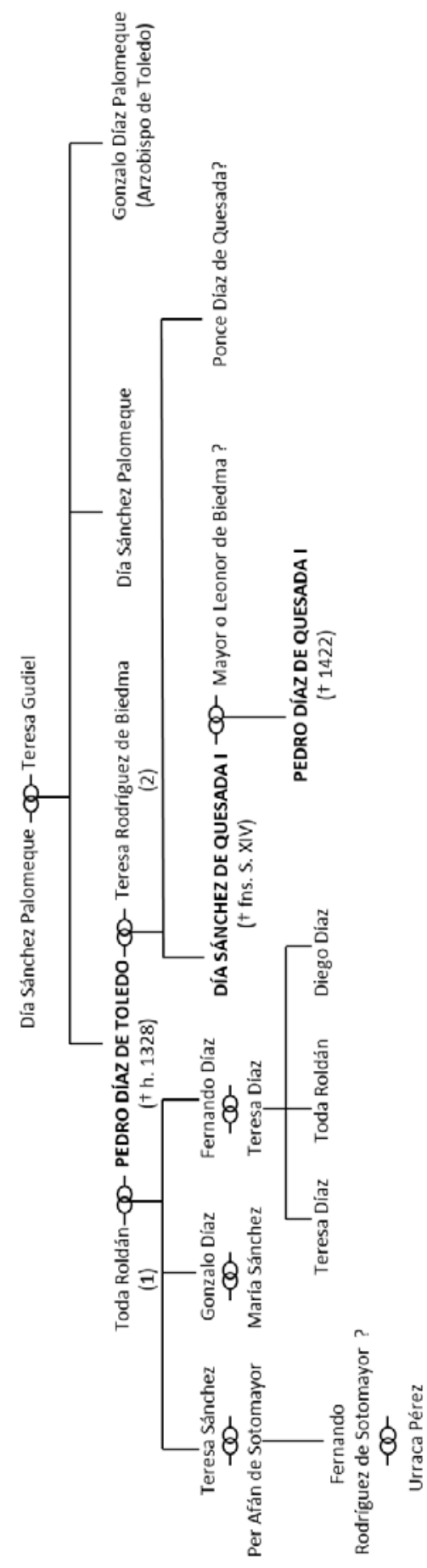




\section{Zona de Influencia de los Quesada}

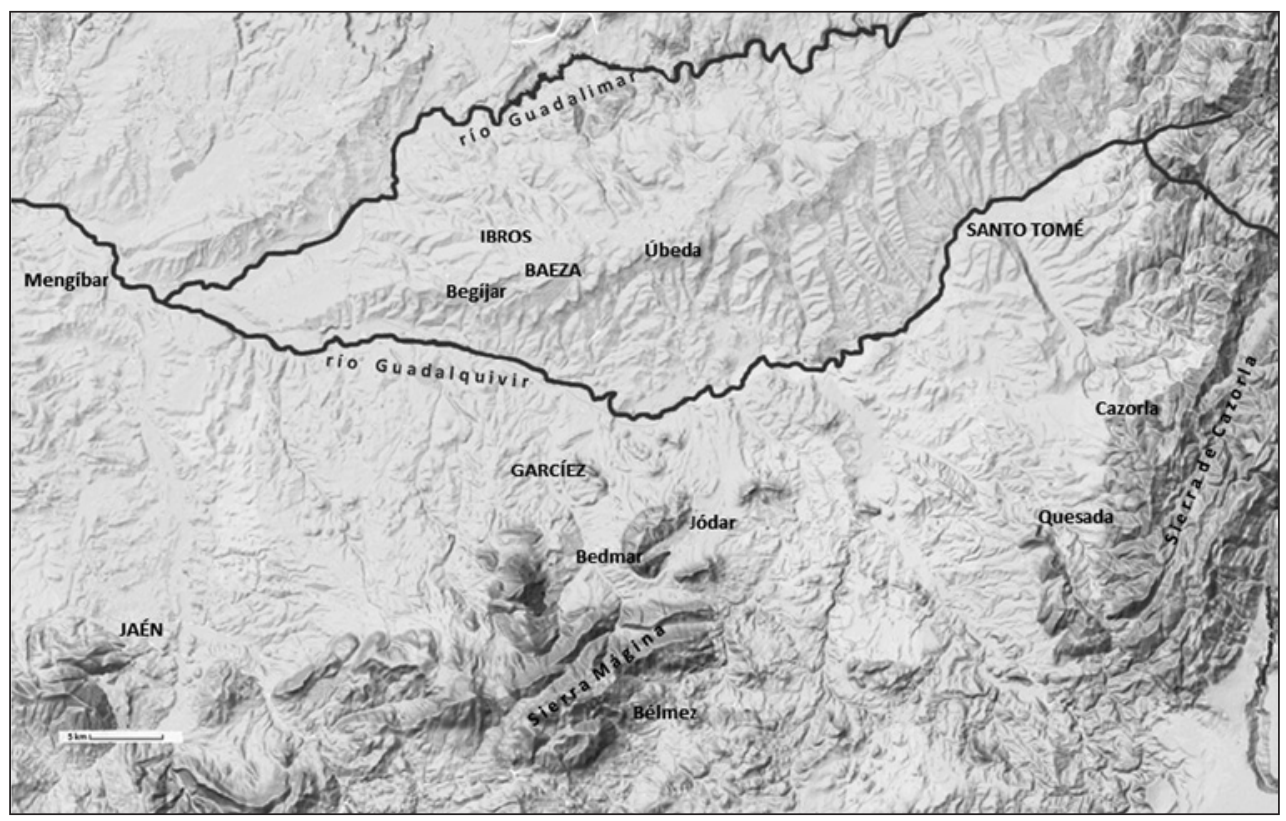

\section{Apéndice documental}

\section{I}

1315, noviembre 28. Jaén

Juan Ponce, otorgó pleito homenaje a Pedro Díaz de Toledo, hermano del arzobispo Gonzalo en razón de la avenencia que entre los dos había pasado sobre el cambio de la torre y cortijo de Garcíez a favor del segundo.

A. Archivo Histórico de Viana, caja 44, exp. 1b/Perg.

Sepan quantos esta carta vieren como yo Juan Ponce otorgo e conozco e fago pleyto omenaje a uos Pedro Díaz de Toledo, hermano del arçobispo don Gonçalo, ante Lope Ruiz e ante çiertos caualleros e omes bonos de Jahén, en raçón del abeneçia que fue entre mí e uos e donna Ynes Anrríquez, mi muger del camio que fizimos del cortijo e de la torre de Garçi Garçiez (sic) de lo que vos y auedes e del castiello de Garçiez de la meatad que yo e donna Ynes Anrriquez, mi muger, auemos en el dicho castiello de Garçiez menos el seysmo, que uos que uos (sic) lo do bien e desenbargadamientre con 
todos sus donadíos e con todas sus pertenençias, así como yo e donna Ynés Anrríquez mi muger lo auemos en el dicho castiello, porque vos podades fazer dello assí commo de uestra cosa propia, et que vos non lo non pueda yo demandar nin embargar nin mi muger ni mis fijos nin otro heredero ninguno que nos ayamos, nin otro ome ninguno que sea daquy que esta carta es fecha adelante por sienpre jamás.

Et si por auentura yo o mi muger o mis fijos o otro ome alguno qualquier a vos quisiesemos demandar o enbargar esto que sobredicho es, que nos non vala. E demás que sea yo traydor por ello, así como quien da castiello e mata señor. E que non pueda saluar por mis manos ni por agenas ni por otra cosa ninguna.

E vos, Pedro Díaz que me podades deçir más por ello vos e quien vos quisieredes. Et otrosí vos fago pleito omenaje, so pena de trayçión que si daquí adelante vos consejaren aquí en Jaén o en Córdoua o en Seuilla o en otra parte qualquier que vos ayades menester más firmes cartas e mejores questas que agora façemos que yo vos las dé quales me las vos demanderedes en esta razón e estas que agora façemos que finquen fechas, e así non lo cumpliere o menguare alguna cosa que sea traydor por esto, así como quien tiene castillo e mata señor. E que non pueda saluar por mis manos ni por ajenas ni por otra manera alguna.

E vos Pedro Díaz que me poderdes dezir mal por ello vos o quien vos quisierdes, et más que esta carta que vos agora do que la tengades por sienpre, e que la mostredes si en alguna cosa menguase desto que dicho es. E demás desto obligamos nos e la dicha donna Ynés Anrríquez mi muger que si alguna cosa destas que dichas son menguásemos y non cumpliésemos, como dicho es, que nos pechemos en pena veinte mill maravedís desta moneda. E para esto cunplir obligamos todos nuestros bienes muebles e rayzes que nos oy día auemos e abremos en abdelante por doquier que los ayamos.

E do poder a vos Pero Díaz o a quien esta carta mostrare por uos que nos podades prendar por esta pena sobredicha sin adelantado e sin alcalde e sin juez e sin otro ome ninguno, e demás que si vos lo refiriere yo o mi muger o mis fijos nin mi mandado que sea por ende aleuoso. Et commo quier que dize de suso por sienpre jamás non queremos que sea más de por un año, dándome vos quales cartas yo demandare por la mi boca porque finque el canuio más en saluo, et qualquier de nos que lo non cumpliese en este año esto que dicho es que finque en la pena de trayçión e en la calonna de los veynte mill maravedís.

Et porque esto sea firme e non venga en dubda di uos ende esta mi carta sellada con mío sello de çera colgado e en que escreuí mi nonbre con mi mano.

Fecha veynte e ocho días de nouienbre era de mill e treçientos e çinquenta e tres años. Yo Ihoan Ponçe. 


\section{8, abril 16. Sevilla}

Urraca Pérez, viuda de Fernando Rodríguez de Sotomayor, residente en el convento de San Clemente de Sevilla, deja en herencia su parte del castillo de Garcíez a Pedro Díaz de Quesada

A. Archivo Histórico de Viana, caja 44, Exp. 1c/Perg.

En lunes diez e seys días de abril era de mill e trezientos e nouenta e seis annos. En este día sobredicho a ora nona, estando dentro en el monesterio de sant Clemente de la muy noble çibdat de Seuilla, en el palaçio do el abadesa del dicho monesterio solía estar que es dentro en el dicho menesterio, e estando y presentes Día Sánchez de Quesada, vasallo de nuestro sennor el rey, et Vrraca Pérez, muger que diz que fue de Ferrant Rodríguez de Sotomayor, sobrina que dixo que era del dicho Día Sánchez, echada en una cama doliente segunt que por ella paresçie, en presençia de mí, Diego Gonçalez escriuano público de la dicha çibdad de Seuilla e de Pero López e Alfon Martínez e de Iohan Martínez escriuanos desta dicha çibdat.

El dicho Día Sánchez dixo a la dicha Vrraca Pérez su sobrina que bien sabía en commo entre el dicho Día Sánchez e la dicha Vrraca Pérez era fecha composiçión ante Gonçalo Martínez, escriuano público desta çibdat, sobre pleito e contienda que era entre ellos amos dos sobrel castiello de Garçiez en que ella que tomaste a Pedro, fijo del dicho Día Sánchez para lo auer. Et que después de sus días della que le dexaua toda la parte e sennorío e heredat que ella auía en el dicho castiello de Garçiez al dicho Pedro, fijo del dicho Día Sánchez. Et la dicha Vrraca Pérez que touiese el dicho castiello de Garçiez en su poder e toda su vida e leuase e ouiese todas las rentas e derechos e frutos e esquilmos del dicho castillo. Et luego la dicha Vrraca Pérez dixo que le plazía de fazer todo lo que con el dicho Día Sánchez posiera, segunt lo el dicho Día Sánchez dezía. Et luego el dicho Día Sánchez preguntó a la dicha Vrraca Pérez sy ella sy quería que tomase por ella pleito e omenage a Gil Ruyz de Villaseca que y estaua presente para que touiese el dicho castiello por ella para gelo diese e gelo entregase cada que ella gelo demandare. Et la dicha Vrraca Pérez dixo luego que non más quel rogaua que dexase este pleito estar agora fasta tras de mannana et que el que veniesse a ella e que le plazía de fazer todo lo quel dicho Día Sánchez quisiese. Et de todo esto en la manera que pasó el dicho Día Sánchez pidió a mí, el dicho Diego González, escriuano público, que gelo diese assy signado e firmado de mí e de los dichos escriuanos que conmigo a ello fueron presentes.

Et yo dígelo fecho el dicho día e ora e mes e era sobredicha. Yo Alfonso Martínez escriuano de Seuilla escreuí este escripto e so testigo (rub). Yo Ihoan Martínez de Seuilla sotestigo (rub). Yo Pero López escriuano de Seuilla so testigo (rub.)

Et yo Diego Gonçalez escriuano público de la muy noble çibdat de Seuilla fiz escriuir este escrito de testimonio e fiz en él mio sig(sig) no (rub.). 


\section{III}

\section{8, abril 23. Sevilla}

Declaración de testigos manifestando que Urraca Pérez, difunta, realizó un codicilo en el que dejaba en herencia a Día Sánchez de Quesada su parte del castillo de Garcíez.

\section{A. Archivo Histórico de Viana, Caja 130, Exp. 44/Perg}

En la muy noble çibdat de Seuilla, lunes veynte e tres días del mes de abril, era de mill e trezientos nouenta seys annos. En este día sobredicho, podía ser a ora de nona, ante Garçía AlfonsoTriguero, alcalde de nuestro señor el rey en la su corte, en presençia de mí, Gonçalo Martínez, escriuano público de la dicha çibdat e de los otros escriuanos que en fin deste ynstrumento escriuieron sus nombres, estando dentro en vnas casas do posa el dicho alguaçil Garçía Alfonso que son en la dicha çibdat, en la collaçión de Sant Román, paresçió Día Sánchez de Quesada, vasallo de nuestro señor el rey et dixo en commo él de la vna parte et Vrraca Pérez su sobrina, muger que fue de Ferrant Rodríguez de Sotomayor, de la otra, al tiempo que era viua, que ouieron en vno pleito ante Domingo Iohan, alcalde en la corte del dicho señor rey sobre el castillo de Garçiez que diz que es en camino de Belmar, logar que diz que es el el obispado de Iahén. E que seguiendo el dicho pleito que antes que fuere fenesçido nin acabado, que la dicha Vrraca Pérez que adoleçió de la dolençia de que finó, et que antes que finase que ordenó e mandó fazer su postrimero testamento en la manera que quiso. Et que después que la dicha Vrraca Pérez ouo ordenado el dicho su testamento, me heredase de algunas cosas que quería enmendar e acreçentar en el dicho su testamento, que fizo cobdeçiello mostrando su póstuma uoluntad ante testigos rogados, porque diz que no pudo auer para esta sazón escriuanos públicos para lo otorgar ante ellos. El qual cobdeçiello e póstuma boluntad que es que la dicha Vrraca Sánchez que mandó al dicho Díag Sánchez que oviese para él toda la parte e el derecho e la boz e la razón que ella auía o podría auer e le paresçe en qualquier manera e por qualquier razón en el dicho castiello de Garçiez e de sus términos en que lo el dicho Día Sánchez oviese para sy después de sus días de la dicha Vrraca Pérez para que podiese dello et en ello fazer todo lo que quisies commo cosa suya. Ende commo dixo que el dicho Día Sánchez que al tienpo e sazón que la dicha Vrraca Pérez fizo el dicho cobdeçiello e manda, que fueron e estauan presentes a ello muchos testigos omes e mugeres dignos de fe e de crençia, porque eran personas priuadas e non públicas, e que algunos dellos que se auían ydo desta tierra, en manera que los non podía auer. Et agora algunos dellos que estauan aquí en esta çibdad, et que sy se fuesen que podería peresçer el derecho que él entendía auer por sus dichos tales, por raçón del dicho cobdiçiello e manda que la dicha Vrraca Pérez le auíe fecho del dicho castiello. Et por esto el dicho Día Sánchez pedió al dicho alcalde Garçía Alfón que seguiendo orden de derecho que de su ofiçio reçibiese juramiento e sopiese verdat de los dichos testigos que él presentase en la razón sobredicha e feziese escreuir sus derechos 
a mí el dicho escriuano, e lo que dixesen e deposiesen en sus testimonios le diese de todo fe e testimonio en pública forma porque lo él ouiese por guarda de su derecho. Et luego el dicho alcalde Garçía Alfonso dixo que por quanto el dicho Día Sánchez le pide derecho que troxiese ante él los otros que él dezía que auía en la dicha razón, et que él faría lo que fallare por derecho. Et luego el dicho Día Sánchez presentó ante el dicho alcalde testigos en la razón sobredicha, de los quales el dicho alcalde reçibió juramento en sanctos euangellios, segunt forma de derecho et mandó a my, el dicho Gonçalo Martínez, escriuano que escriuiese e reçibiese sus sichos preguntándoles por cada vno de los agrauios e razones sobredichos. Et yo fízelo asy, los quales testigos e lo que dixeron es todo esto que se sigue.

Iohan Rodríguez de Biedma, fijo de Ferrant Ruyz de Biedma, jurado e preguntado por la jura que fizo, dixo que este lunes que agora pasó que fue diez e seys días del dicho mes de abril de la era sobredicha, podía ser a ora de bísperas, que él que fue con el dicho Día Sánchez de Quesada, éste por quien viene en prueua al monesterio de Sant Clemeynte de Seuilla que es en esta dicha çibdat. Et que fallaron dentro en el dicho monesterio a la dicha Vrraca Pérez que estaua dolliente en cama, e quel dicho Día Sánchez et este dicho Ihoan Rodríguez et otros omes que y estauan que se llegaron a la cama donde la dicha Vrraca Pérez estaua et que vido e oyó en commo el dicho Día Sánchez dixo a la dicha Vrraca Pérez sobrina: Bien sabedes de commo yo e vos auemos pleito sobre el castiello de Garçiez, et en commo Gil Ruyz de Villasan fizo pleito e omenaje por el dicho castiello a mi e a vos, et pues vos estades agora dolliente, por vos fazer plazer e sauedes más ayna, quiero quel dicho Gil Ruyz que fagua (sic) el dicho pleito e omenaje todo a uos por el dicho castillo. Et otrosy, yo quiero fazer sobre el dicho pleito que en vno auemos todo lo que vos quisierdes. E diz que vido e oyó estonçe que la dicha Vrraca Pérez que dixo a Día Sánchez: Digo vos que mi voluntad tenía puesto de dar la parte que yo he en el dicho castiello a Pedro vuestro fijo para que lo oviese por suyo después de mis días, mas pues esto los agora querádes, quiero e plázeme que sy yo finare desta dolençia, que ayades para vos toda la parte que yo he en el dicho castiello. Et otrosí, dixo que le plazía de fazer e guardar e conplir todo lo que con el dicho Día Sánchez auía puesto en razón del dicho castiello. Et que commo quiera que ella antes desto auía fecho e ordenado su testimonio siguiendo su volundad porque ella agora que mandaua quel dicho Día Sánchez que ouiese toda la parte e derecho que ella aúa en el dicho castillo de Garçiez para que lo ouiese él para sy después de sus días dela dicha Vrraca Pérez. Et otrosí, que mandó quel dicho castillo que él fuese dado et entregado al dicho Día Sánchez o a quien él mandase, e que sy contra esto o contra parte dello testimonio o manda auía fecho que fuese contra esto, que ella lo reuocaua todo et que no vido ni sabe más desto que dicho ha.

Diego López de Porras, uezino que diz que es en esta dicha çibdat a la collaçión de Sant Viçente, jurado e preguntado por la jura que fizo, dixo que este lunes que agora pasó que fue diez e seys días del dicho mes de abril de la era sobredicha podía ser a ora de vísperas, que él que fue con el dicho Día Sánchez de Quesada este por quien viene en prueua al monesterio de Sant Clemeynte de Seuilla que es en esta dicha çibdat, et que fallaron dentro en el dicho monesterio a la dicha Vrraca Pérez que estaua dolliente en 
cama. Et quel dicho Día Sánchez e este dicho Diego López et otros omes que y estauan que se lleguaron a la cama donde la dicha Vrraca Pérez estaua et que vido et oyó en commo el dicho Día Sánchez dixo a la dicha Vrraca Pérez: Sobrina, bien sabedes, de commo yo e vos auemos pleito sobre el castiello de Garçiez, et en commo Gil Ruyz de Villasán fizo pleito e omenaje por el dicho castiello a mí e a uos, e pues vos e estades agora dolliente, por vos fazer plazer e sauedes más ayna, quiero que dicho Gil Ruyz que faga el dicho pleito e omenaje todo a uos por el dicho castillo. Et otrosy, yo quiero fazer sobre el dicho pleito que en vno auemos todo lo que vos que vos quisierdes. Et diz que vido e oyó estonçe que la dicha Vrraca Pérez que dixo: Día Sánchez, digo vos que es mi voluntad tenía puesto de dar la parte que yo he en el dicho castiello a Pedro vuestro fijo para que lo ouiere por suyo después de mis días, mas pues esto vos agora después, quiero e plázeme que sy yo finare desta dolençia que ayades para vos toda la parte que yo he en el dicho castiello. Et otrosí dixo que le plazía de fazer e guardar e conplir todo lo que con el dicho Día Sánchez auía puesto en razón del dicho castillo. Et commo quier que ella antes desto aúa fecho e ordenado su testamento seguiendo su voluntad, pero que agora que mandaua quel dicho Día Sánchez ouiese toda la parte e derecho que ella auía en el dicho castillo de Garçiez para que lo oviese él para sy después de sus días de la dicha Vrraca Pérez. Et otrosí, que mandó quel dicho castillo que le fuese dado e entregado al dicho Día Sánchez, o aquien él mandare. Et que sy contra esto o contra parte dello testamento o manda aúa fecho, que fuese nunca esto, que ella lo reuocaua todo et que non vido nin sabe más desto que dicho ha.

Gonçalo Martínez de la cámara del rey, jurado e preguntado por la jura que fizo, dixo que este lunes que agora pasó que fue diez e seys días del dicho mes de abril de la era sobredicha, podría ser a ora de bísperas, que él que fue con el dicho Día Sánchez de Quesada, este por quien viene en prueua al monestario de Sant Clemeynte de Seuilla, que es en esta dicha çibdat, et que fallaron dentro en el dicho monesterio a la dicha Vrraca Pérez que estaua dolliente en cama, e al dicho Día Sánchez. Et este dicho Gonçalo Martínez e otros omes que y estauan que se lleguaron (sic) a la cama donde la dicha Vrraca Pérez estaua, et que vido e oyó en commo el dicho Día Sánchez dixo a la dicha Vrraca Pérez: Sobrina bien sabedes de commo yo e vos auíemos pleito sobre el castiello de Garçiez, et en commo Gil Ruyz de Villasan fizo pleito e omenaje por el dicho castiello a mí e a bos, e pues vos estades agora dolliente por vos fazer plazer e sauedes más ayna quiero quel dicho Gil Ruyz que fagua el dicho pleito e omenaje todo a uos por eldicho castillo. Et otrosí, yo quiero fazer sobre el dicho pleito que en vno auiemos todo lo que vos quisierdes. Et diz que vido e oyó estonçe que la dicha Vrraca Pérez que dixo Día Sánchez: Digo vos que mi voluntad tenía puesto de dar la parte que yo he en el dicho castiello a Pedro vuestro fijo que lo ouiese por suyo después de mis días, mas pues esto vos agora dezides quiero e plázeme que sy yo firmare desta dolençia que ayades que vos toda la parte que yo he en el dicho castiello. Et otrosí dixo que le plazía de fazer e guardar e conplir todo lo que con el dicho Día Sánchez aya puesto en razón del dicho castillo, et commo quier que ella ante desta auía fecho e ordenado su testimonio seguiendo su voluntad porque ella agora que mandaua quel dicho Día Sánchez que ouiese toda la parte e derecho que ella auía en 
el dicho castillo de Garçiez para que los ouiese él para sy después de sus días de la dicha Vrraca Pérez. Et otrosí, mandó que dicho castillo que le fuese dado e entregado al dicho Día Sánchez o a quien mandase. E que sy contra esto o contra parte dello testamento o manda auía fecho, que fuese contra esto que ella lo reuocaua todo. Et que non vido nin sabe más desto que dicho ha.

Alfonso Ferrández de Alua de Céspedes?, criado de Lope Garçía de Porras, jurado y preguntado por la jura que fizo dixo que este lunes que agora pasó que fue diez e seys días del dicho mes de abril de la era sobre, podía ser hora de bísperas, que él que fue con el dicho Día Sánchez de Quesada este por quien viene en parte al monesterio de Sant Clemeynte de Seuilla que es en esta dicha çibdat, et que fallaron dentro en el dicho monesterio a la dicha Vrraca Pérez que estaua dolliente en cama, et quel dicho Sánchez e este dicho Alfonso Ferrández e otros omes que y estauan que se lleguaron a la cama donde la dicha Vrraca Pérez estaua et que vido e oyó en commo el dicho Día Sánchez dixo a la dicha Vrraca Pérez: Sobrina bien sabedes de commo yo e bos auemos pleito sobre el castillo de Garçiez, et en commo Gil Ruyz de Villasanta fizo pleito e omenaje por el dicho castillo a mí e a uos, e pues vos estades agora dolliente por les fazer plazer e sauedes más ayna que quiero que el dicho Gil Ruyz que fagua el dicho pleito e omenaje todo a uos por el dicho castillo. Et otrosy yo quiero fazer sobre el dicho pleito que en vno auemos todo los que vos quisierdes. Et diz que vido e oyó estonçe que la dicha Vrraca Pérez que dixo Día Sánchez: Digo uos que mi uoluntad tenía puesto de dar la parte que yo he en el dicho castiello a Pedro vuestro fijo para que lo ouiese por suyo después de mis días, mas pues esto nos agora dezides, quiero e plazóme que sy yo finare desta dolençia que ayades para vos toda la parte que yo he en el dicho castillo. E otrosy dixo que le plazía de fazer e guardar e conplir todo lo con el dicho Día Sánchez auía puesto en razón del dicho castillo. Et que comoquier que ella antes desto auía fecho et ordenado su testamento seguiendo su voluntad, pero que ella agora mandaua quel dicho Día Sánchez que ouiese toda la parte e derecho que ella auía en el dicho castiello de Garçiez para que lo ouiese él para sy después de sus días de la dicha Vrraca Pérez. Et otrosí que mandó quel dicho castillo que le fuese dado e entregado al dicho Día Sánchez o a quien él mandase. Et que sy contra esto o contra parte dello testamento o manda auía fecho que fuese contra esto que ello lo reuocaua todo, et que no vido nin sabe más desto que dicho ha.

Et desto en commo pasó el dicho Día Sánchez pedió ansí el dicho Gonçalo Martínez, escriuano público que le diese ende vn testimonio en forma pública firmado e signado. E yo dige lo fecho del dicho Día e mes e era sobredicha. Yo Lope Alfonso, escriuano de Seuilla, so testigo (rub). Yo Matheos Sánchez escriuano de Seuilla so testigo (rub). Yo Garçi Alfon (rub).

Et yo Gonçalo Martínez, escriuano público de la muy noble çibdat de Seuilla lo fize escreuir e puse en el mio sig (sig) no e so testigo (rub.).

Fecha de recepción: 3 de enero de 2017

Fecha de aceptación: 30 de abril de 2017 
